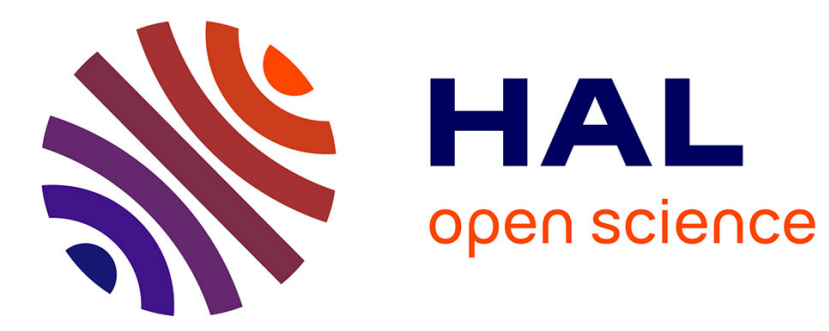

\title{
Compression Behaviour of Natural and Reconstituted Clays
}

Zhenshun Hong, Ling-Ling Zeng, Yu-Jun Cui, Yuan-Qiang Cai, Cheng Lin

\section{To cite this version:}

Zhenshun Hong, Ling-Ling Zeng, Yu-Jun Cui, Yuan-Qiang Cai, Cheng Lin. Compression Behaviour of Natural and Reconstituted Clays. Geotechnique, 2012, 62 (4), pp.291-301. 10.1680/geot.10.P.046 . hal-00693382

\section{HAL Id: hal-00693382 \\ https://hal-enpc.archives-ouvertes.fr/hal-00693382}

Submitted on 2 May 2012

HAL is a multi-disciplinary open access archive for the deposit and dissemination of scientific research documents, whether they are published or not. The documents may come from teaching and research institutions in France or abroad, or from public or private research centers.
L'archive ouverte pluridisciplinaire HAL, est destinée au dépôt et à la diffusion de documents scientifiques de niveau recherche, publiés ou non, émanant des établissements d'enseignement et de recherche français ou étrangers, des laboratoires publics ou privés. 


\section{Compression Behaviour of Natural and Reconstituted Clays}

Zhen-Shun Hong ${ }^{1}$, Ling-Ling Zeng ${ }^{2}$, Yu-Jun Cui ${ }^{3}$, Yuan-Qiang Cai ${ }^{4}$, Cheng Lin $^{5}$

1: Professor, Ph.D, Institute of Geotechnical Engineering, School of Transportation, Southeast University, Nanjing 210096, P. R. China

2: Lecturer, Ph.D, Institute of Geotechnical Engineering, College of Civil Engineering, Fuzhou University, Fuzhou 350108, P. R. China

3: Professor, Ph.D, Ecole des Ponts - ParisTech, UR Navier/CERMES, 6 et 8, avenue Blaise Pascal, Cité Descartes, Champs-sur-Marne, 77455 Marne La Vallée cedex 2, France

4: Professor, Ph.D, College of Architecture and Civil Engineering, Wenzhou University, Wenzhou 325035, P. R. China

5: Doctoral Student, Department of Civil, Environmental, \& Architectural Engineering (CEAE), the University of Kansas, Lawrence, Kansas 66045-7609, USA

\section{Corresponding Author:}

Zhen-Shun Hong, Ph.D, Professor

Institute of Geotechnical Engineering, School of Transportation

Southeast University

Nanjing 210096, P. R. China

P. R. China

Email: zshong@seu.edu.cn 


\begin{abstract}
The intercept of the $\log (1+e)-\log \sigma_{v}{ }^{\prime}$ straight line is introduced to describe the effect of the starting point on the compressibility of natural and reconstituted clays. It is found that when the effective stress exceeds the remoulded yield stress, the compression behaviour of reconstituted clays is controlled solely by the water content at the remoulded yield stress and the liquid limit. Comparison of the compression behaviour of natural and reconstituted clays indicates that their difference in compressibility is caused by soil structure and the difference in water content at the compression starting point. The compression behaviour of natural clays can be classified into three regimes: 1) the pre-yield regime characterised by small compressibility with soil structure restraining the deformation up to the consolidation yield stress; 2) the transitional regime characterised by a gradual loss of soil structure when the effective stress is between the consolidation yield stress and the transitional stress; and 3) the post-transitional regime characterised by the same change law in compression behaviour as reconstituted clays when the effective stress is higher than the transitional stress. For the investigated clays, the transitional stress is 1.0-3.5 times the consolidation yield stress. The compression index varies solely with the void ratio at an effective stress of $1.0 \mathrm{kPa}$ for both natural clays in post-transitional regime and reconstituted clays when the effective stress exceeds the remoulded yield stress, and when compressed in such cases the compression curves of both natural clays and reconstituted clays can be normalised well to a unique line using the void index.
\end{abstract}

KEYWORDS: clays; compressibility; soil structure; laboratory tests 


\section{NOTATION}

$\sigma_{\mathrm{t}}{ }^{\prime}=$ transitional stress

$\sigma_{\mathrm{yr}}{ }^{\prime}=$ remoulded yield stress

$\sigma_{\mathrm{v}}{ }^{\prime}=$ effective vertical stress

$\sigma_{\mathrm{vy}}{ }^{\prime}=$ consolidation yield stress

$\mathrm{C}_{\mathrm{c}}=\left(\mathrm{e}_{100}-\mathrm{e}_{1000}\right)$

$\mathrm{C}_{\mathrm{c}}{ }^{*}=\left(\mathrm{e}^{*}{ }_{100}-\mathrm{e}^{*}{ }_{1000}\right)$

$\mathrm{C}_{\mathrm{CL}}=$ compression index of natural clays in $\log (1+e)-\log \sigma_{v}{ }^{\prime}$ plot

$\mathrm{C}_{\mathrm{CLR}}=$ compression index of reconstituted clays in $\log (1+e)-\log \sigma_{v}{ }^{\prime}$ plot

$\mathrm{e}=$ void ratio

$\mathrm{e}_{1}=$ void ratio at $\sigma_{v}{ }^{\prime}=1 \mathrm{kPa}$

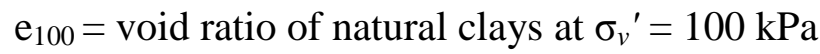

$\mathrm{e}_{1000}=$ void ratio of natural clays at $\sigma_{v}{ }^{\prime}=1000 \mathrm{kPa}$

$\mathrm{e}^{*}{ }_{100}=$ void ratio of reconstituted clays at $\sigma_{v}{ }^{\prime}=100 \mathrm{kPa}$

$\mathrm{e}^{*} 1000=$ void ratio of reconstituted clays at $\sigma_{v}{ }^{\prime}=1000 \mathrm{kPa}$

$\mathrm{e}_{\mathrm{L}}=$ void ratio at liquid limit

$\mathrm{e}_{\mathrm{yr}}=$ void ratio at remoulded yield stress

$\mathrm{e}_{\mathrm{vy}}=$ void ratio at consolidation yield stress

EICL $=$ extended intrinsic compression line

$\mathrm{ICL}=$ intrinsic compression line

$\mathrm{I}_{\mathrm{v}}=$ void index, equal to $\left(\mathrm{e}-\mathrm{e}^{*}{ }_{100}\right) /\left(\mathrm{e}^{*}{ }_{100}-\mathrm{e}^{*}{ }_{1000}\right)$

$I_{v n}=$ void index for natural clays, equal to $\left(e-e_{100}\right) /\left(e_{100}-e_{1000}\right)$

pre-yield regime $=$ effective vertical stress lower than consolidation yield stress

post-transitional regime $=$ effective vertical stress higher than transitional stress

post-yield regime $=$ effective vertical stress higher than consolidation yield stress

$r=$ coefficient of correlation

transitional regime $=$ effective stress higher than consolidation yield stress but lower than transitional stress

$\mathrm{w}_{\mathrm{L}}=$ liquid limit

$\mathrm{w}_{\mathrm{n}}=$ natural water content

$\mathrm{w}_{\mathrm{yr}}=$ water content at remoulded yield stress 


\section{INTRODUCTION}

Natural clays generally have a compression curve (in terms of void ratio $e$ versus effective vertical stress $\sigma_{v}{ }^{\prime}$ in the semi-logarithmic plane) lying above that of reconstituted clays owing to the effect of soil structure (e.g. Leroueil et al., 1979; Leroueil et al., 1985; Locat \& Lefebvre, 1986; Leroueil \& Vaughan, 1990; Schmertmann, 1991; Cotecchia \& Chandler, 1997; Hong \& Tsuchida 1999). It is common practice to refer to reconstituted clays when assessing the effect of soil structure on the mechanical behaviour of natural sedimentary clays (e.g. Skempton \& Northey, 1953; Houston \& Mitchell, 1969; Nagaraj \& Srinivasa Murthy, 1986; Hight et al., 1987; Burland, 1990; Liu \& Carter, 1999; Hong \& Tsuchida, 1999; Chandler, 2000; Cotecchia \& Chandler, 2000; Liu \& Carter, 2000). It has been recognised that the soil structure restrains the deformation of natural clays under effective vertical stress up to the consolidation yield stress, consequently resulting in the low compressibility of clays until the stress level exceeds the consolidation yield stress (e.g. Butterfield, 1979; Holtz et al., 1986; Burland, 1990). The difference of void ratio between natural clays and reconstituted clays at the same stress level often increases with increasing consolidation stress up to the consolidation yield stress, but decreases when the applied stress level is larger than the consolidation yield stress (e.g. Liu \& Carter, 1999; Hong \& Tsuchida, 1999; Liu \& Carter, 2000). Leroueil et al. (1985) classified the compressive behaviour of natural clays into two states: the intact state as it occurs in natural deposits; and the destructured state referring to the breakdown of the original clay structure when submitted to volumetric or shear deformations. The former is related to elastic deformation whereas the latter is related to elasto-plastic deformation.

The main parameters affecting the compressibility of natural clays in the destructured state are not well understood. It should be noted that the void ratio or the water content at the consolidation yield stress for natural clays is different from that of reconstituted clays. Hence, the difference in compressive behaviour between destructured natural clays and the reconstituted clays cannot be directly attributed to soil structure without considering the effect of the starting state on compressibility. As a result, the following questions arise: 1) what is the fundamental mechanism responsible for the compressive behaviour of natural clays at the destructured state defined by Leroueil et al. (1985), i.e., when the stress level is greater than the consolidation yield stress? 2) how does the soil structure of natural clays degrade with increasing stress when the stress level reaches and exceeds the consolidation yield stress? 3) what is the fundamental mechanism which causes the difference in compressibility between natural clays and reconstituted clays?

With these questions in mind, changes in compressibility are first discussed in this paper based on oedometer test data for reconstituted clays having different initial water contents and different liquid limits, in an attempt to clarify the fundamental mechanism responsible for the compressive behaviour of reconstituted clays. Then, the compression behaviour of natural clays is investigated, and compared with that of reconstituted clays in order to understand the role of soil structure during consolidation when the effective stress is greater than the consolidation yield stress. 
Finally, the normalised compression behaviour of natural clays is analysed and compared with that of reconstituted clays in order to better understand the mechanism responsible for the difference in compression behaviour between natural clays and reconstituted clays.

\section{FUNDAMENTAL MECHANISM FOR CHANGE IN COMPRESSBILITY OF RECONSTITUTED CLAYS DURING CONSOLIDATION}

Hong et al. (2010) performed 42 oedometer tests to investigate the compression behaviour of three reconstituted clays (Lianyungang clay; Baimahu clay; and Kemen clay) with a wide range of initial water contents, as shown in Table 1 . The test results illustrate an inverse " $\mathrm{S}$ " shape of the $e-\log \sigma_{v}$ ' compression curves, as typically shown in Figure 1, similar to those of many natural clays. This similarity in shape of the $e-\log \sigma_{v}{ }^{\prime}$ compression curves between natural clays and reconstituted clays indicates that there is a particular stress for reconstituted clays which is similar to the consolidation yield stress for natural clays. As for the compression behaviour of natural clays, the compression curves of reconstituted clays can be divided into two lines which intersect at a particular stress. Small compressibility occurs when the effective stress is lower than this particular stress, which acts in a similar role to the consolidation yield stress of natural clays. Mitchell (1993) called this particular stress the 'pore water suction', and indicated that the liquid limit for all fine-grained soils corresponds to about $6.0 \mathrm{kPa}$ of pore water suction and about 1.7-2.0 kPa of shearing resistance. Hong et al. (2010) termed the particular stress as suction pressure. Herein, it is termed as the remoulded yield stress $\sigma_{y r}{ }^{\prime}$ to avoid confusion with descriptions of the behaviour of unsaturated soils.

As typically shown in Figure 1, the compressibility of a reconstituted clay increases dramatically when the effective stress is higher than the remoulded yield stress. For a given reconstituted clay, the compressibility of a reconstituted clay is affected by the starting point $\left(\sigma_{y r}{ }^{\prime}, e_{y r}\right)$ of the compression line whenever the effective vertical stress is higher than the remoulded yield stress. The $e_{y r}$ is the void ratio at the remoulded yield stress $\sigma_{y r}{ }^{\prime}$. Hence, the compression index $C_{c}{ }^{*}$ depends on the values of the remoulded yield stress and the void ratio at the remoulded yield stress. Note that the compression index of reconstituted clays is defined as (Burland, 1990):

$$
C_{c}^{*}=\left(e^{*} 100-e^{*} 1000\right)
$$

where $e^{*}{ }_{100}$ and $e^{*}{ }_{1000}$ are the void ratios of the reconstituted clays at the effective vertical stresses $\sigma_{v}{ }^{\prime}$ of $100 \mathrm{kPa}$ and $1000 \mathrm{kPa}$, respectively. The starting point $\left(\sigma_{y r}{ }^{\prime}, e_{y r}\right)$ for reconstituted clays is similar to the starting point $\left(\sigma_{v y}^{\prime}, e_{v y}\right)$ of the post-yield line for natural clays when the effective stress is greater than the consolidation yield stress. Note that the terms of $\sigma_{v y}{ }^{\prime}, e_{v y}$ represent the consolidation yield stress and the void ratio at the consolidation yield stress, respectively.

To investigate the effect of the starting point $\left(\sigma_{y r^{\prime}}{ }^{\prime}, e_{y r}\right)$ on the compressibility of reconstituted clays at effective vertical stress levels higher than the remoulded yield stress, the oedometer test data for Lianyungang clay, Baimahu clay, and Kemen clay reported by Hong et al. (2010) were considered here. The relationships of $C_{c}{ }^{*}$ versus $e_{y r}$ and $C_{c}{ }^{*}$ versus $\sigma_{y r}{ }^{\prime}$ are given in Figures 2 and 3 respectively. For a given clay, the 
compression index $C_{c}{ }^{*}$ increases with increase in void ratio at the remoulded yield stress $e_{y r}$, and decreases with increase in the remoulded yield stress $\sigma_{y r}{ }^{\prime}$. It can be also found that at the same value of $e_{y r}$ or at the same value of $\sigma_{y r}^{\prime}$, the parameter $C_{c}{ }^{*}$ decreases in the order of Baimahu clay, Lianyungang clay and Kemen clay. Interestingly, it coincides with the order of decreasing liquid limits (see Table 1). These results indicate that the compression index $C_{c}{ }^{*}$ is greatly affected by the parameters $e_{y r}, \sigma_{y r}{ }^{\prime}$ and the liquid limit $w_{L}$. Hence, an index is needed to consider the combined effects of $e_{y r}, \sigma_{y r}{ }^{\prime}$, and $w_{L}$ on the compression behaviour of reconstituted clays with different starting points $\left(\sigma_{y r}{ }^{\prime}, e_{y r}\right)$ and different liquid limits.

It has been well documented that the $e-\log \sigma_{v}{ }^{\prime}$ compression curves with an inverse "S" shape for many natural clays can be represented by two straight lines in a plot of $\log (1+e)$ or $\ln (1+e)$ against $\log \sigma_{v}{ }^{\prime}$ or $\ln \sigma_{v}{ }^{\prime}$ (e.g. Hashiguchi \& Ueno, 1977; Butterfield, 1979; Onitsuka et al., 1995; Sridharan \& Prakash, 1996; Hong \& Onitsuka, 1998; Hong, 2007). Hong et al. (2010) illustrated that the bilogarithmic method can be also used to represent well the inversely S-shaped $e-\log \sigma_{v}{ }^{\prime}$ compression curves of reconstituted clays by two straight lines. The stress at the intersection point of the two straight lines is the consolidation yield stress and the remoulded yield stress for natural clays and reconstituted clays, respectively. Hence, the following equations can be obtained for expressing the compression curves of natural clays in the post-yield regime and those of reconstituted clays for the effective vertical stress higher than the remoulded yield stress:

$$
\begin{array}{lc}
\log (1+\mathrm{e})=\log \left(1+\mathrm{e}_{1}\right)-\mathrm{C}_{\mathrm{CLR}} \times \log \sigma_{\mathrm{v}}{ }^{\prime} \quad \text { (for reconstituted clays) } \\
\log (1+\mathrm{e})=\log \left(1+\mathrm{e}_{1}\right)-\mathrm{C}_{\mathrm{CL}} \times \log \sigma_{\mathrm{v}}{ }^{\prime} \quad \text { (for natural clays) }
\end{array}
$$

The parameter $e_{1}$ is the void ratio at an effective vertical stress of $1 \mathrm{kPa}$, and $C_{C L}$ and $C_{C L R}$ represent the compression index of natural clays and reconstituted clays in the $\log (1+e)-\log \sigma_{v}{ }^{\prime}$ plot, respectively.

It is indicated in Equations (2) and (3) that the intercept of the straight post-yield line of a natural clay or the straight line of a reconstituted clay for the effective vertical stress higher than the remoulded yield stress corresponds to $\log \left(1+e_{1}\right)$, and is simply represented by the parameter $e_{1}$. Figure 4 schematically shows the concept of $e_{1}$ for a given reconstituted clay with different initial water contents. As reported by Hong et al. (2010), the starting point $\left(\sigma_{y r}{ }^{\prime}, e_{y r}\right)$ varies with the initial water content. The higher the initial water content, the greater is the void ratio at the remoulded yield stress, the lower is the remoulded yield stress. It can be observed in Figure 4 that a unique value of $e_{1}$ can be expected for a given position of $\left(\sigma_{y r}{ }^{\prime}, e_{y r}\right)$. That is, for a given clay with a certain liquid limit, the difference in initial water content will result in different positions of $\left(\sigma_{y r}{ }^{\prime}, e_{y r}\right)$, and in turn different values of $e_{1}$. In the same fashion, reconstituted clays with different liquid limits but at the same initial water content still have different starting points of the compression lines with the effective vertical stress higher than the remoulded yield stress, consequently resulting in different values of $e_{1}$. It should be mentioned that the parameters $e_{y r}, \sigma_{y r}{ }^{\prime}$, and liquid limit are not disassociated each other; they are related with the following equation as described by Hong et al. (2010):

$$
\mathrm{e}_{\mathrm{yr}} / \mathrm{e}_{\mathrm{L}}=\mathrm{w}_{\mathrm{yr}} / \mathrm{w}_{\mathrm{L}}=2 /\left(\sigma_{\mathrm{yr}}\right)^{0.42}
$$


where the remoulded yield stress $\sigma_{y r}{ }^{\prime}$ is expressed in $\mathrm{kPa}$; the parameter $e_{L}$ represents the void ratio at liquid limit; the parameter $w_{y r}$ is the water content at the remoulded yield stress. Equation (4) indicates that given a certain value of one parameter among $e_{y r}, \sigma_{y r}{ }^{\prime}$ and $e_{L}$, the other two parameters vary unambiguously. That is, the reconstituted clays having different liquid limits or different initial water contents certainly have different positions $\left(\sigma_{y r}{ }^{\prime}, e_{y r}\right)$, and thus different values of $e_{1}$. Hence, the void ratio at $1 \mathrm{kPa}\left(e_{1}\right)$ can reflect the combined effects of $e_{y r}, \sigma_{y r}{ }^{\prime}$, and $e_{L}$ on the compression behaviour of reconstituted clays. In this study, the index $e_{1}$ is used for comparison of the compressibility of various reconstituted clays at different initial water contents.

Figure 5 shows the relationship between $C_{c}{ }^{*}$ and $e_{1}$ for the three reconstituted clays based on the oedometer test data reported by Hong et al. (2010). It is interesting to note that the $C_{c}{ }^{*}$ increases solely with increase in $e_{1}$ for the three clays at different initial water contents and with different liquid limits. This confirms that the index $e_{1}$ can reflect the effect of the starting state $\left(\sigma_{y r}{ }^{\prime}, e_{y r}\right)$ on the compressibility of various reconstituted clays at different initial water contents when the effective vertical stress is higher than the remoulded yield stress. For further investigating the effects of the starting points of the compression lines at the effective vertical stress higher than the remoulded yield stress, the test data for other reconstituted clays compiled from the available literature shown in Table 1 were used to establish the relationship between $C_{c}{ }^{*}$ and $e_{1}$. The liquid limits of the reconstituted clays cover a wide range from $37 \%$ to $220 \%$. All the data were obtained from multi-stage loading oedometer tests. As discussed by Hong et al. (2010), the $\log (1+e)-\log \sigma_{v}{ }^{\prime}$ plot is appropriate for interpreting the oedometer test data for Lianyungang clay, Baimahu clay and Kemen clay by two straight lines. These three clays were tested using a modified oedometer apparatus with the first applied vertical stress as low as $0.5 \mathrm{kPa}$. The other reconstituted clays listed in Table 1 from the available literature were tested in conventional oedometers with a first vertical stress generally higher than the remoulded yield stress. The oedometer test data for these reconstituted clays can be interpreted by a straight line in the $\log (1+e)-\log \sigma_{v}{ }^{\prime}$ plot, as typically shown in Figure 6. The correlation coefficients for the 90 reconstituted clays, $r$, reach as high as 0.97-1.00, most being larger than 0.99. Figure 7 shows the relationship between $C_{c}{ }^{*}$ and $e_{1}$ for all the 90 reconstituted clays investigated, including data of the three clays reported by Hong et al. (2010). It is interesting to note that a unique relationship is obtained with the data reported by independent researchers. A regression analysis gives the following equation with a correlation coefficient $r$ of 0.99 .

$$
\mathrm{C}_{\mathrm{c}}^{*}=0.183 \mathrm{e}_{1}-0.0021\left(\mathrm{e}_{1}\right)^{2}
$$

The unique relationship of $C_{c}{ }^{*}$ versus $e_{1}$ indicates that when the effective vertical stress is higher than the remoulded yield stress, the compression index $C_{c}{ }^{*}$ of a reconstituted clay depends solely on the starting state, and is a function of the void ratio at the remoulded yield stress and the liquid limit.

On the other hand, Hong et al. (2010) reported that the $e-\log \sigma_{v}{ }^{\prime}$ compression curves of various reconstituted clays with different initial water contents can be normalised well with respect to the void index $I_{v}$ when the effective vertical stress is 
higher than the remoulded yield stress; whereas it is not the case at the effective vertical stress being smaller than the remoulded yield stress, in which the compression curves lie on the left of the normalised line, and the $I_{v}-\log \sigma_{v}{ }^{\prime}$ curve with a higher initial water content lies above that with a lower initial water content, as typically shown in Figure 8.

The void index $I_{v}$ is defined by Burland (1990) as follows.

$$
\mathrm{I}_{\mathrm{v}}=\left(\mathrm{e}-\mathrm{e}^{*}{ }_{100}\right) /\left(\mathrm{e}^{*}{ }_{100}-\mathrm{e}^{*}{ }_{1000}\right)=\left(\mathrm{e}-\mathrm{e}^{*}{ }_{100}\right) / \mathrm{C}_{\mathrm{c}}{ }^{*}
$$

The normalised compression curve for reconstituted clays at different initial water contents and with different liquid limits is designated as the extended intrinsic compression line (EICL) by Hong et al. (2010), which can be expressed as:

$$
\mathrm{I}_{\mathrm{v}}=3.0-1.87 \log \sigma_{v}{ }^{\prime}+0.179\left(\log \sigma_{v}{ }^{\prime}\right)^{2}
$$

where $\sigma_{v}{ }^{\prime}$ is expressed in $\mathrm{kPa}$. The EICL extends the intrinsic compression line (ICL) of Burland (1990) to wider ranges for both of the initial water content and the effective vertical stress: $0.7-2.0$ times the liquid limit and as low as $1.5 \mathrm{kPa}$, respectively. It was demonstrated that when the effective vertical stress is higher than $25 \mathrm{kPa}$, the EICL coincides with the ICL suggested by Burland (1990) which is expressed by Equation (8).

$$
\mathrm{I}_{\mathrm{v}}=2.45-1.285 \log \sigma_{v}{ }^{\prime}+0.015\left(\log \sigma_{v}{ }^{\prime}\right)^{3}
$$

where $\sigma_{v}{ }^{\prime}$ is expressed in $\mathrm{kPa}$. Within the range of effective stress from $1.5 \mathrm{kPa}$ to about $10 \mathrm{kPa}$, the EICL lies a little above the ICL (Hong et al., 2010). Note that Burland (1990) suggested that ICL should be used only for effective vertical stress ranging from $10 \mathrm{kPa}$ to $4000 \mathrm{kPa}$. All the 90 reconstituted clays have a normalised behaviour of compression curves with respect to the void index only if the effective vertical stress is higher than the remoulded yield stress, the same as Figure 8 of this study and Figure 13 in Hong et al. (2010).

\section{COMPARISON OF COMPRESSBILITY BETWEEN NATURAL CLAYS AND RECONSTITUTED CLAYS}

It has been well known that the compression behaviour of natural clays differs from that of remoulded clays, as schematically shown in Figure 9. Although the undisturbed and the remoulded specimens have the same initial water content (i.e. natural water content $w_{n}$ ), the consolidation yield stress of the undisturbed specimen is higher than the remoulded yield stress due to the soil structure formed during the depositional and the post-depositional processes. Hence, the compression starting point of the post-yield line for the undisturbed specimen differs from that of the remoulded specimen at the remoulded yield stress. That is, the water content or the void ratio of a natural clay at the consolidation yield stress is greater than that of the reconstituted clay at the same stress. As illustrated in the previous section, the compressibility of reconstituted clay is greatly affected by the water content at the starting point. The difference in water content at the starting point between natural clays and remoulded clays should be an important factor responsible for the difference in compressibility. In the same fashion as in the analysis for the compression behaviour of reconstituted clays, the index $e_{1}$ is also adopted to analyse the difference in compressibility between natural clays and reconstituted clays. For this purpose, the 
relationships between the compression index and the parameter $e_{1}$ for various natural clays should be established, and then compared with Equation (5) established based on reconstituted clays to clarify the role of water content on the difference in compressibility between reconstituted clays and natural clays. The data for the natural clays investigated here includes Ariake clays and other clays compiled from the available literature. For comparison purposes, the compression index $C_{c}$ of natural clays is defined as:

$$
C_{c}=\left(e_{100}-e_{1000}\right)
$$

where $e_{100}$ and $e_{1000}$ are the void ratios of natural clays at effective vertical stresses $\sigma_{v}{ }^{\prime}$ of $100 \mathrm{kPa}$ and $1000 \mathrm{kPa}$, respectively.

The oedometer test data for natural Ariake clays were disposed here to investigate the compressibility of natural clays, as shown in Table 2. These data were used by Hong \& Han (2007) for quantitatively evaluating the degrees of sample disturbance. The clays have a wide spectrum of liquid limits, ranging from $34 \%$ to $140 \%$. These data can be also interpreted well by two straight lines in the $\log (1+e)-\log \sigma_{v}{ }^{\prime}$ plot, as typically shown in Figure 10. The relationship between $C_{c}$ and $e_{1}$ for all the investigated 119 Ariake specimens listed in Table 2 is shown in Figure 11. The relationship from Equation (5) for reconstituted clays is also plotted in the same figure for comparison. It is interesting to note that the parameter $C_{c}$ has a unique relationship with the parameter $e_{1}$ for all the natural Ariake clays investigated; more importantly, the relationship between $C_{c}$ and $e_{1}$ for natural Ariake clays is consistent with the relationship of $C_{c}{ }^{*}$ versus $e_{1}$ for reconstituted clays. This indicates that the compression index $C_{c}$ for natural Ariake clays should be the same as the compression index $C_{c}{ }^{*}$ for reconstituted clays, if they have the same value of $e_{1}$. In other words, the difference in compressibility between undisturbed and remoulded specimens of a given natural Ariake clay is caused by the difference in the starting point as schematically shown in Figure 9. Consequently, the compressibility of the natural Ariake clays investigated depends solely on the void ratio or the water content at the consolidation yield stress and the liquid limit, when the applied stress reaches and exceeds the consolidation yield stress. Such a result suggests that once the effective vertical stress overcomes the consolidation yield stress, which is the result of complex geological processes involving deposition environment, consolidation, erosion, thixotropic hardening, leaching, weathering etc. as described by Leroueil et al. (1985), the natural Ariake clays investigated have the same change law in compression behavior as the corresponding reconstituted clays.

In order to further compare the compressibility of other natural clays with reconstituted clays, the oedometer test data of other natural clays were compiled from the available literature, as shown in Table 3. Similar to the reconstituted clays listed in Table 1 and the natural Ariake clays in Table 2, all the data were obtained from multi-stage loading oedometer tests. The liquid limits range from $34 \%$ to $122 \%$, and the natural water contents vary from $41 \%$ to $120 \%$. As aforementioned, the index $e_{1}$ can be used to assess the compressibility of natural clays when they have a linear $\log (1+e)-\log \sigma_{v}{ }^{\prime}$ line in the post-yield regime. However, there are two types of compression curves for the natural clays listed in Table 3, as typically shown in Figure 
12. The oedometer test data for the natural clays of Type one can be interpreted by two straight lines in the $\log (1+e)-\log \sigma_{v}{ }^{\prime}$ plot, like the natural Ariake clays listed in Table 2. But the compression curves for the natural clays of Type two have a transitional drop zone just after the consolidation yield stress is exceeded. That is, there are three zones in the $\log (1+e)-\log \sigma_{v}{ }^{\prime}$ plot. The range of stress for the middle zone varies from the consolidation yield stress to the transitional stress $\sigma_{t}{ }^{\prime}$. The transitional stress is defined as the stress responsible for the starting point of the third straight line defining for the behaviour of Type two clays. Its value is about 1.4-3.5 times the consolidation yield stress for the investigated clays, as shown in Figure 13. The behaviour of Type one clays may be considered as a special case of the behaviour of Type two clays, in which the range of stress from the consolidation yield stress to the transitional stress is extremely narrow. The above phenomenon implies that the shape of compression curves and the degradation of the soil structure associated with the irreversible deformation for various natural clays may depend on the specific mechanism responsible for the presence of soil structure. The existence of the transitional regime implies the gradual change in microstructure during consolidation associated with the relatively large deformation in the transitional regime. The absence of the transitional regime indicates a dramatic change in microstructure at the vicinity of the consolidation yield stress associated with little change in deformation, as illustrated by Hong et al. (2006). Several researchers have investigated the change in microstructure of soils during consolidation (e.g. Collins \& McGown, 1974; Delage \& Lefebvre, 1984; Griffiths \& Joshi, 1989; Tanaka \& Locat, 1999; Hong et al., 2006). However, more studies on changes in microscopic level during consolidation are needed in the future to better understand the mechanisms responsible for the existence of the transitional regime in some natural clays and for absence in others.

In the analysis of the natural clays of Type two, the value of $e_{1}$ is obtained by extending the third straight line after the transitional stress up to the effective vertical stress of $1 \mathrm{kPa}$. Figure 14 gives the relationship between $C_{c}$ and $e_{1}$ for the natural clays listed in Table 3, including both Type one and Type two clays. It can be seen that the relationship for natural clays of Type one in the post-yield regime is consistent with that of Type two clays when the effective vertical stress is higher than the transitional stress. It is encouraging to note that the relationship for natural clays listed in Table 3 is almost identical to that by Equation (5) established based on reconstituted clays, even though the test data were compiled from literature reported by independent researchers.

The above analysis illustrates that the compression behaviour of natural clays can be classified into three regimes: 1) the pre-yield regime with small compressibility when the effective stress is lower than the consolidation yield stress; 2) the transitional regime with gradual loss of soil structure when the effective stress is higher than the consolidation yield stress but lower than the transitional stress; and 3) the post-transitional regime when the effective stress is higher than the transitional stress, in which natural clays have the same change law in compression behaviour as reconstituted clays. In some cases, the transitional zone can be ignored when the transitional stress is close to the consolidation yield stress. 
Note that the three regimes mentioned above for natural soils are important for both theoretical development and practice. When modelling the compression behaviour of natural clays, it is clear that the three regimes should be accounted for by adopting different equations; in practice, much attention should be paid on the transitional regime because this regime corresponds to an unstable soil state and the compression behaviour is characterised by a 'collapse' nature.

\section{NORMALISED BEHAVIOUR OF NATURAL CLAYS}

For normalising the compression behaviour of natural clays, the void index $I_{v n}$ is introduced with $e_{100}$ and $C_{c}$ instead of $e_{100}{ }^{*}$ and $C_{c}{ }^{*}$ in Equation (6), expressed as follows.

$$
\mathrm{I}_{\mathrm{vn}}=\left(\mathrm{e}-\mathrm{e}_{100}\right) /\left(\mathrm{e}_{100}-\mathrm{e}_{1000}\right)=\left(\mathrm{e}-\mathrm{e}_{100}\right) / \mathrm{C}_{\mathrm{c}}
$$

It should be pointed out that unlike the remoulded yield stress of reconstituted clays, the consolidation yield stress of Type one clay or the transitional stress of Type two clay may be greater than $100 \mathrm{kPa}$. In such a case, $e_{100}$ is situated in the pre-yield regime or in the transitional regime. Consequently, it can no longer be used for calculating the void index to normalise the compression curves. To tackle this problem, the values of $e_{100}$ are determined by extrapolating the linear post-transitional bilogarithmic line.

The compression curves of natural Ariake clays shown in Figure 10 were normalised with the void index $I_{v n}$ defined in Equation (10), as shown in Figure 15. It can be seen that the relationship between the void index $I_{v n}$ and the effective vertical stress for the six natural Ariake clays become a unique line when the effective vertical stress is higher than the consolidation yield stress; whereas the oedometer test data in the pre-yield regime cannot be normalised. Such normalised behaviour of natural Ariake clays is similar to that of various reconstituted clays at different initial water contents. Figure 16 shows the normalised values of $I_{v n}$ in the post-yield regime for all the natural Ariake clays investigated. The intrinsic compression line (ICL) and the extended intrinsic compression line (EICL) are also shown in the same figure for comparisons. It can be seen that the oedometer test data of 119 natural Ariake clays can be normalised with the void index defined in Equation (10), when the data is in the post-yield regime. It is interesting to note that when the effective vertical stress is higher than $40 \mathrm{kPa}$, the normalised behaviour of natural Ariake clays can be expressed well by the intrinsic compression line (ICL) which was proposed by Burland (1990) based on the test data of reconstituted clays. However, the experimental data of natural Ariake clays lie a little above the ICL, and closer to the EICL when the effective vertical stress is lower than $20 \mathrm{kPa}$.

The oedometer test data of Figure 12 were re-plotted in the form of the void index $I_{v n}$ versus $\log \sigma_{v}{ }^{\prime}$, as shown in Figure 17. It can be seen that the clays of Type one can be normalised well with the void index $I_{v n}$ when the effective vertical stress is higher than the consolidation yield stress. This normalised behaviour is the same as that of the natural Ariake clays (see Figure 15). However, for Type two clays, only if the effective vertical stress is higher than the transitional stress, can the compression curves be normalised with the void index $I_{v n}$. Within the range of stress level from the 
consolidation yield stress to the transitional stress, the values of $I_{v n}$ for Type two clays lie above the normalised line, and gradually converge toward the ICL when the effective stress approaches the transitional stress. The compression curves normalised with respect to $I_{v n}$ for Type one clays listed in Table 3 in the post-yield regime are also compared with the ICL (see Figure 18), showing that they are identical. Figure 19 gives the normalised oedometer test data for Type two clays listed in Table 3 with the effective vertical stress higher than the transitional stress. It can be seen that the normalised data are also consistent with the intrinsic compression line (ICL). The above results indicate that the compression curves of natural clays can be normalised well with regard to the void index defined by Equation (10) when the effective vertical stress is higher than the transitional stress; whereas the compression curves of natural clays in the pre-yield regime and in the transitional regime cannot be normalised with the void index.

\section{CONCLUSIONS}

When the effective stress is greater than the remoulded yield stress for reconstituted clays or larger than the transitional stress for natural clays, the extrapolated void ratio at an effective stress of $1.0 \mathrm{kPa}\left(e_{1}\right)$ can be used as a powerful index for reflecting the combined effects of both the initial water content at the starting point and the liquid limit on compressibility, and the compression index increases uniquely with increase in $e_{1}$ for all the investigated reconstituted and natural clays having a wide range of liquid limits. The unique relationship can be expressed as $C_{c}{ }^{*}=0.183 e_{1}-0.0021\left(e_{1}\right)^{2}$.

The compressibility of a reconstituted clay depends on three parameters: the remoulded yield stress, the void ratio at the remoulded yield stress and the liquid limit. When the effective stress is lower than the remoulded yield stress, the compressibility is mainly controlled by the remoulded yield stress which restrains the deformation in the same fashion as the consolidation yield stress of natural clays. When the effective stress is larger than the remoulded yield stress, the compressibility of a reconstituted clay depends solely on the void ratio at the remoulded yield stress and the liquid limit.

The compression behaviour of a natural clay can be classified into three regimes: the pre-yield regime characterised by small compressibility up to the consolidation yield stress with soil structure restraining the deformation; the transitional regime with gradual loss of soil structure when the effective stress is between the consolidation yield stress and the transitional stress; and the post-transitional regime characterised by the same change law in compression behaviour as a reconstituted clay when the effective stress is higher than the transitional stress. In some cases, the transitional zone can be ignored if the transitional stress is close to the consolidation yield stress.

The compression curves of both natural clays in the transitional regime and reconstituted clays when the effective stress is larger than the remoulded yield stress can be normalised well with the void index, consistent with the normalised compression line (ICL) for reconstituted clays suggested by Burland (1990). 


\section{ACKNOWLEDGEMENTS}

This study is supported by the National Natural Science Foundation of China (Grant No. 41172240; Grant No. 50878050). The authors are grateful to Dr Jie Yin, Mr Xia Bian, and Mr Qinghua Wang for their help during the preparation of the manuscript.

\section{REFERENCES}

Allman, M. A. \& Atkinson, J. H. (1992). Mechanical properties of reconstituted Bothkennar soil. Géotechnique 42, No. 2, 289-301.

Burland, J. B. (1990). On the compressibility and shear strength of natural clays. Géotechnique 40, No. 3, 329-378.

Butterfield, R. (1979). A natural compression law for soils. Géotechnique 29, No. 4, 469-480.

Cerato, A. B. \& Lutenegger, A. J. (2004). Determining intrinsic compressibility of fine-grained soils. Journal of Geotechnical and Geoenvironmental Engineering, Proc. Am. Soc. Civ. Engrs 130, No. 8, 872-877.

Chandler, R. J. (2000). Clay sediments in depositional basin: the Geotechnical Cycle. The Quarterly Journal of Engineering Geology and Hydrology 33, No. 1, 7-39.

Chung, S. G., Nagendra Prasad, K., Nagaraj, T. S., Chung, J. G. \& Jo, K. Y. (2004). Assessment of compressibility behavior of naturally cemented soft clays. Marine Georesources and Geotechnology 22, No.1, 1-20.

Collins, K. \& McGown, A. (1974). The form and function of microfabric features in a variety of natural soils. Géotechnique 24, No. 2, 223-254.

Cotecchia, F. \& Chandler, R. J. (1997). The influence of structure on the pre-failure behaviour of a natural clay. Géotechnique 47, No. 3, 523-544.

Cotecchia, F. \& Chandler, R. J. (2000). A general framework for the mechanical behaviour of clays. Géotechnique 50, No. 4, 431-447.

Delage, P. \& Lefebvre, G. (1984). Study of the structure of a sensitive Champlain clay and of its evolution during consolidation. Canadian Geotechnical Journal 21, No. 1, 21-35.

Feng, T. W. (1991). Compressibility and permeability of natural soft clays and surcharging to reduce settlement. $\mathrm{PhD}$ thesis, University of Illinois at Urbana-Champaign.

Giao, P. H., Dung, N. T. \& Long, P. V. (2008). Integrated geotechnical-geophysical investigation of soft clay at a coastal site in the Mekong Delta for oil and gas infrastructure development. Can. Geotech. J. 45, No. 11, 1514-1524.

Griffiths, F. J. \& Joshi, R. C. (1989). Change in pore size distribution due to consolidation of clays. Géotechnique 39, No. 1, 159-167.

Hashiguchi, K. \& Ueno, M. (1977). Elasto-plastic constitutive laws of granular materials. IX Int. Conf. Soil Mech. Found. Engrg., Tokyo: Balkema, Rotterdam, Specialty Session 9, pp. 73-82.

Hight, D. W., Jardine, R. J. \& Gens, A. (1987). The behaviour of soft clays. Chapter 2, Embankment on soft clays, Athens: Public Works Research Centre of Greece, pp. 33-158. 
Hight, D. W., Bond, A. J. \& Legge, J. D. (1992). Characterization of the Bothkennar clay: an overview. Géotechnique 42, No. 2, 303-347.

Holtz, R. D., Jamiolkowski, M. \& Lancellotta, R. (1986). Lessons from oedometer tests on high quality samples. Journal of Geotechnical Engineering Division, Proc. Am. Soc. Civ. Engrs 112, No. 8, 768-776.

Hong, Z. \& Onitsuka, K. (1998). A method of correcting yield stress and compression index of Ariake clays for sample disturbance. Soils and Foundations 38, No. 2, 211-222.

Hong, Z. \& Tsuchida, T. (1999). On compression characteristics of Ariake clays. Canadian Geotechnical Journal 36, No. 5, 807-814.

Hong, Z., Tateishi, Y. \& Han, J. (2006). Experimental study of macro and micro-behavior of natural diatomite. Journal of Geotechnical and Geoenvironmental Engineering, Proc. Am. Soc. Civ. Engrs 132, No. 5, 603-610.

Hong, Z. (2007). Void ratio-suction behavior of remolded Ariake clays. Geotechnical Testing Journal 30, No. 3, 234-239.

Hong, Z. \& Han, J. (2007). Evaluation of sample quality of sensitive clay using intrinsic compression concept. Journal of Geotechnical and Geoenvironmental Engineering, Proc. Am. Soc. Civ. Engrs 133, No. 1, 83-90.

Hong, Z., Yin, J. \& Cui, Y. (2010). Compression behaviour of reconstituted soils at high initial water contents. Géotechnique 60, No. 9, 691-700.

Houston, W. N. \& Mitchell, J. K. (1969). Property interrelationships in sensitive clays. Journal of the Soil Mechanics and Foundations Division, Proc. Am. Soc. Civ. Engrs 95, No. 4, 1037-1062.

Leroueil, S., Tavenas, F., Brucy, F., La Rochelle, P. \& Roy, M. (1979). Behavior of destructured natural clays. Journal of Geotechnical Engineering, Proc. Am. Soc. Civ. Engrs 105, No. 6, 759-778.

Leroueil, S., Tavenas, F. \& Locat, J. (1985). Discussion on "Correlations between index tests and the properties of remolded clays". Géotechnique 35, No. 2, 223-226.

Leroueil, S. \& Vaughan, P. R. (1990). The general and congruent effects of structure in natural soils and weak rocks. Géotechnique 40, No. 3, 467-488.

Liu, M. D. \& Carter, J. P. (1999). Virgin compression of structured soils. Géotechnique 49, No. 1, pp. 43-57.

Liu, M. D. \& Carter, J. P. (2000). Modelling the destructuring of soils during virgin compression. Géotechnique 50, No. 4, 479-483.

Locat, J. \& Lefebvre, G. (1986). The origin of structuration of the Grande-Baleine marine sediments, Québec, Canada. Q. J. Engng. Geol. 19, No. 4, 365-374.

Locat, J. \& Lefebvre, G. (1983). The compressibility and sensitivity of an artificially sedimented clay soil: The Grande-Baleine Marine Clay, Quebes, Canada. Marine Geotechnology 6, No.1, 1-28.

Low, H. E., Phoon, K. K., Tan, T. S. \& Leroueil, S. (2008). Effect of soil microstructure on the compressibility of natural Singapore marine clay, Can. Geotech. J. 45, No 2, 161-176.

Mesri, G. \& Olson, R. E. (1971). Consolidation characteristics of montmorillonite. 
Géotechnique 21, No. 4, 341-352.

Mitchell, K. (1993). Fundamentals of soil behavior (2 ${ }^{\text {nd }}$ edition). New York: John Wiley \& Sons, Inc.

Nagaraj, T. S. \& Srinivasa Murthy, B. R. (1983). Rationalization of Skempton's compressibility equation. Géotechnique 33, No. 4, 433-443.

Nagaraj, T. S. \& Srinivasa Murthy, B. R. (1986). A critical reappraisal of compression index equation. Géotechnique 36, No. 1, 27-32.

Nagaraj, T. S., Pandian, N. S. \& Narasimha Rgju, P. S. R. (1993). Stress state-permeability relations for fine-grained soil. Géotechnique 43, No. 2, 333-336.

Onitsuka, K., Hong, Z., Hara, Y. \& Yoshitake, S. (1995). Interpretation of oedometer test data for natural clays. Soils and Foundations 35, No. 3, 61-70.

Quigley, R. M. \& Ogunbadejo, T. A. (1972). Clay layer fabric and oedometer consolidation of a soft varved clay. Can. Geotech J. 9, No. 2, 165-175.

Schmertmann, J. H. (1991). The mechanical aging of soils. Journal of Geotechnical Engineering, Proc. Am. Soc. Civ. Engrs. 117, No. 9, 1288-1330.

Silvestri, V. (1984). Discussion on "preconsolidation pressure of Champlain clay, Part II". Can. Geotech. J. 21, No. 3, 600-602.

Skempton, A. W. \& Northey, R. D. (1953). The sensitivity of clays. Géotechnique 3, No. 1, 30-53.

Sridharan, A. \& Prakash, K. (1996). Discussion on "interpretation of oedometer test data for natural clays." Soils and Foundations 36, No. 3, 146-148.

Sridharan A. \& Nagaraj, H. B. (2000). Compressibility behavior of remolded, fine-grained soils and correlation with index properties. Can. Geotech. J. 37, No. 3, 712-722.

Tanaka, H. \& Locat, J. (1999). A microstructural investigation of Osaka Bay clay: the impact of microfossils on its mechanical behaviour. Canadian Geotechnical Journal 36, No. 3, 493-508.

Tavenas, F., Leblond, P., Jean, P. \& Leroueil, S. (1983). The permeability of natural soft clays. Part II: Permeability characteristics. Can. Geotech J. 20, No. 4, 645-660.

Watabe, Y., Udaka, K., Kobayashi, M., Tabata, T. \& Emura, T. (2008). Effects of friction and thickness on long-term consolidation behavior of Osaka Bay clays. Soils and Foundations 48, No 4, 547-561.

Yong, R. N. \& Nagaraj, T. S. (1977). Investigation of fabric and compressibility of sensitive clay. Geotechnical aspects of soft clays: proceeding of the international symposium on soft clay, pp. 327-333. 


\section{List of Tables and Figures}

Table 1. Sources of reconstituted clays

Table 2. Physical indices of natural Ariake clays

Table 3. Sources of natural clays from literature

Fig. 1. Typical e $-\log \sigma_{\mathrm{v}}{ }^{\prime}$ compression curves of reconstituted clays at different initial water contents based on Hong et al. (2010)

Fig. 2. Relationship between $\mathrm{C}_{\mathrm{c}}{ }^{*}$ and $\mathrm{e}_{\mathrm{yr}}$ for three reconstituted clays at different initial water contents

Fig. 3. Relationship between $\mathrm{C}_{\mathrm{c}}{ }^{*}$ and $\sigma_{\mathrm{yr}}{ }^{\prime}$ for three reconstituted clays at different initial water contents

Fig. 4. Effect of starting points on compressibility for a given clay at different initial water contents

Fig. 5. Relationship between $\mathrm{C}_{\mathrm{c}}{ }^{*}$ and $\mathrm{e}_{1}$ for three reconstituted clays at different initial water contents

Fig. 6. Typical $\operatorname{linear} \log (1+\mathrm{e})-\log \sigma_{\mathrm{v}}{ }^{\prime}$ lines of reconstituted clays at $\sigma_{\mathrm{v}}{ }^{\prime}>\sigma_{\mathrm{yr}}{ }^{\prime}$

Fig. 7. Relationship of $\mathrm{C}_{\mathrm{c}}{ }^{*}$ versus $\mathrm{e}_{1}$ for all 90 reconstituted clays

Fig. 8. Typical $I_{v}-\log \sigma_{v}{ }^{\prime}$ curves of reconstituted clays at different initial water contents

Fig. 9. Comparison of the starting points between undisturbed and remoulded specimens of natural clays

Fig. 10. Typical compression curves of natural Ariake clays in $\log (1+\mathrm{e})-\log \sigma_{\mathrm{v}}{ }^{\prime}$ plot

Fig. 11. Relationship between $\mathrm{C}_{c}$ and $\mathrm{e}_{1}$ for 119 natural Ariake clays

Fig. 12. Typical compression curves of two types of natural clays listed in Table 3

Fig. 13. Relationship between transitional stress and consolidation yield stress for natural clays of Type two listed in Table 3

Fig. 14. Relationship between $\mathrm{C}_{\mathrm{c}}$ and $\mathrm{e}_{1}$ for the two types of natural clays listed in Table 3

Fig. 15. Typical normalized behaviour of natural Ariake clays with void index $\mathrm{I}_{\mathrm{vn}}$

Fig. 16. Normalised line of 119 natural Ariake clays in post-yield regime

Fig. 17. Typical normalised behaviour with void index $I_{v n}$ for two types of natural clays listed in Table 3

Fig. 18. Normalised behaviour with void index $I_{v n}$ for natural clays of Type one in post-yield regime

Fig. 19. Normalised behaviour with void index $I_{v n}$ for natural clays of Type two with effective vertical stresses larger than transitional stresses 
Table 1. Sources of reconstituted clays

\begin{tabular}{|c|c|c|c|c|c|}
\hline Soils & $\begin{array}{l}\text { Initial water content } \\
\qquad(\%) \\
\end{array}$ & $\begin{array}{l}\text { Liquid limit } \\
(\%) \\
\end{array}$ & $\begin{array}{c}\text { Plastic limit } \\
(\%) \\
\end{array}$ & $\begin{array}{l}\text { Density of soil particles } \\
\qquad\left(\mathrm{g} / \mathrm{cm}^{3}\right) \\
\end{array}$ & Source of data \\
\hline Calcium montmorillonite Clay & 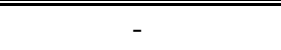 & $189-220$ & $31-35$ & 2.80 & Mesri \& Olson (1971) \\
\hline Sail Clay & 158 & 158 & - & 2.83 & Nagaraj \& Srinivasa (1983) \\
\hline Black Cotton Clay & $84-97$ & $84-97$ & - & $2.65-2.73$ & Nagaraj \& Srinivasa (1983); Nagaraj et al. (1993) \\
\hline Red Soil & $39-50$ & $37-50$ & $18-27$ & $2.63-2.70$ & Nagaraj \& Srinivasa (1983); Nagaraj et al. (1993); Sridharan \& Nagaraj (2000) \\
\hline Brown Soil & $58-62$ & $59-62$ & - & 2.65 & Nagaraj et al. (1993); Sridharan \& Nagaraj (2000) \\
\hline Bentonite Clay & 300 & 300 & 70 & 2.80 & Nagaraj \& Srinivasa (1983) \\
\hline Bothkennar Clay & $65-85$ & $67-85$ & $24-41$ & $2.64-2.80$ & Hight et al. (1992); Allman \& Atkinson (1992) \\
\hline Silty Soil & 39 & 39 & 30 & 2.65 & Sridharan \& Nagaraj (2000) \\
\hline Cochin Clay & 56 & 56 & 38 & 2.61 & Sridharan \& Nagaraj (2000) \\
\hline Illitic Soil & 73 & 73 & 52 & 2.58 & Sridharan \& Nagaraj (2000) \\
\hline BC Soil & 74 & 74 & 36 & 2.70 & Sridharan \& Nagaraj (2000) \\
\hline Kaolinite Clay & $42-74$ & $42-59$ & $26-45$ & $2.64-2.68$ & Sridharan \& Nagaraj (2000); Cerato \& Lutenegger (2004) \\
\hline Attapulgite Clay & $202-354$ & 202 & 108 & 2.83 & Cerato \& Lutenegger (2004) \\
\hline Atchafalaya Clay & $101-177$ & 101 & 35 & 2.80 & Cerato \& Lutenegger (2004) \\
\hline Boston Blue Clay & $45-79$ & 45 & 23 & 2.80 & Cerato \& Lutenegger (2004) \\
\hline Lianyungang Clay & $50-146$ & 74 & 33 & 2.71 & Hong et al. (2010) \\
\hline Baimahu Clay & $64-180$ & 91 & 38 & 2.65 & Hong et al. (2010) \\
\hline Kemen Clay & $43-122$ & 61 & 30 & 2.67 & Hong et al. (2010) \\
\hline
\end{tabular}


Table 2. Physical indices of natural Ariake clays

\begin{tabular}{ccccccc}
\hline Locations of Ariake clays & Depth & Natural water content & Liquid limit & Plastic limit & Density of soil particles & Source of data \\
& $(\mathrm{m})$ & $(\%)$ & $(\%)$ & $(\%)$ & $\left(\mathrm{g} / \mathrm{cm}^{3}\right)$ & Hong and Han $(2007)$ \\
\hline \hline Ashikari & $2-38$ & $30-124$ & $34-100$ & $17-41$ & $2.48-2.67$ & $2.37-2.66$ \\
Hama & $1-18$ & $71-168$ & $39-129$ & $23-53$ & $2.58-2.68$ & \\
Ariake & $2-40$ & $31-145$ & $66-140$ & $20-47$ & $2.51-2.67$ & \\
Fukudomi & $2-14$ & $32-149$ & $44-103$ & $21-49$ & & \\
\hline
\end{tabular}


Table 3. Sources of natural clays from literature

\begin{tabular}{|c|c|c|c|c|c|c|c|}
\hline Soils & $\begin{array}{l}\text { Depth } \\
\text { (m) }\end{array}$ & $\begin{array}{l}\text { Natural water content } \\
\qquad(\%)\end{array}$ & $\begin{array}{l}\text { Liquid limit } \\
\qquad(\%)\end{array}$ & $\begin{array}{c}\text { Plastic limit } \\
(\%)\end{array}$ & $\begin{array}{l}\text { Density of soil particles } \\
\qquad\left(\mathrm{g} / \mathrm{cm}^{3}\right)\end{array}$ & Type & Source of data \\
\hline Varved clay & $15-31$ & $53-60$ & $69-73$ & $24-26$ & $2.73-2.75$ & Type one & Quigley \& Ogunbadejo (1972) \\
\hline Bothkennar & $5-14$ & $59-83$ & $71-85$ & $26-41$ & - & Type one & Hight et al. (1992) \\
\hline Shniho clay & $18-31$ & $50-66$ & $53-67$ & $14-33$ & $2.63-2.69$ & Type one & Chung et al. (2004) \\
\hline Jangyu clay & $6-18$ & $63-100$ & $57-69$ & $22-31$ & $2.69-2.72$ & Type one & Chung et al. (2004) \\
\hline Eulsookdo clay & $21-35$ & $44-59$ & $42-59$ & $17-26$ & $2.65-2.72$ & Type one & Chung et al. (2004) \\
\hline Kimhae clay & $13-22$ & $41-47$ & $37-47$ & $16-28$ & $2.72-2.73$ & Type one & Chung et al. (2004) \\
\hline Mekong Delta clay & $2-14$ & $74-79$ & $69-72$ & $37-38$ & - & Type one & Giao et al. (2008) \\
\hline Osaka Bay clays & 73 & 69 & 100 & 38 & - & Type one & Watabe et al. ( 2008 ) \\
\hline Singapore marine clay & $25-41$ & - & $82-92$ & - & $2.74-2.79$ & Type one & Low et al. (2008) \\
\hline Champlain clay & - & $70-75$ & $50-60$ & $25-28$ & 2.80 & Type two & Yong \& Nagaraj (1977); Silvestri (1984) \\
\hline Grande-Baleine clay & - & - & 34 & 21 & - & Type two & Locat \& Lefebvre (1983) \\
\hline Backebol clay & 50 & 81 & 74 & 28 & - & Type two & Tavenas et al. (1983) \\
\hline Batiscan clay & - & $86-88$ & 49 & 22 & 2.80 & Type two & Feng (1991) \\
\hline Berthierville clay & - & $57-63$ & 46 & 24 & 2.80 & Type two & Feng (1991) \\
\hline St.-Hilaire clay & - & $65-84$ & 55 & 23 & 2.80 & Type two & Feng (1991) \\
\hline Vasby clay & - & $102-120$ & $108-122$ & $36-41$ & 2.75 & Type two & Feng (1991) \\
\hline
\end{tabular}




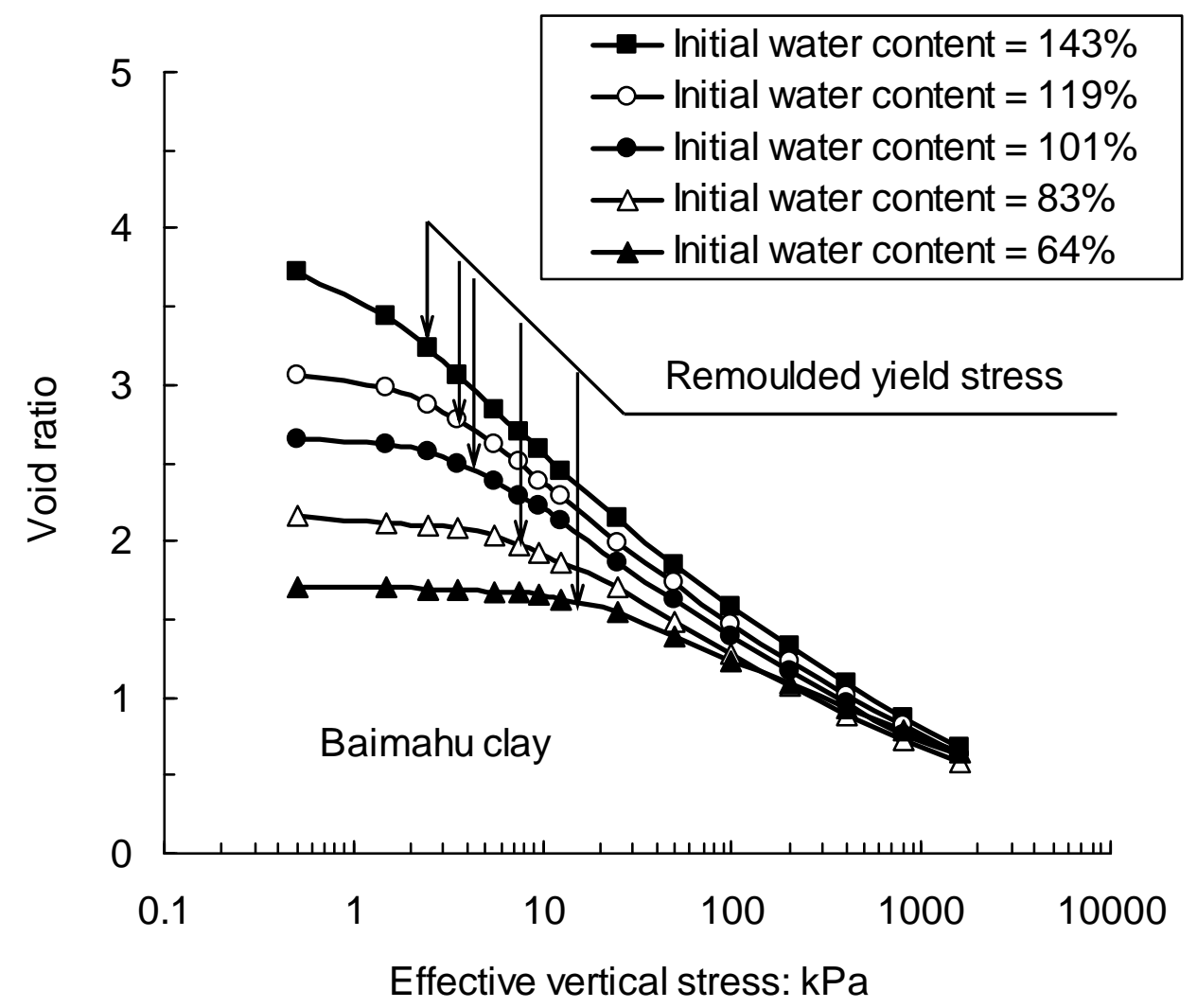

Fig. 1. Typical $e-\log \sigma_{v}{ }^{\prime}$ compression curves of reconstituted clays at different initial water contents based on Hong et al. (2010) 


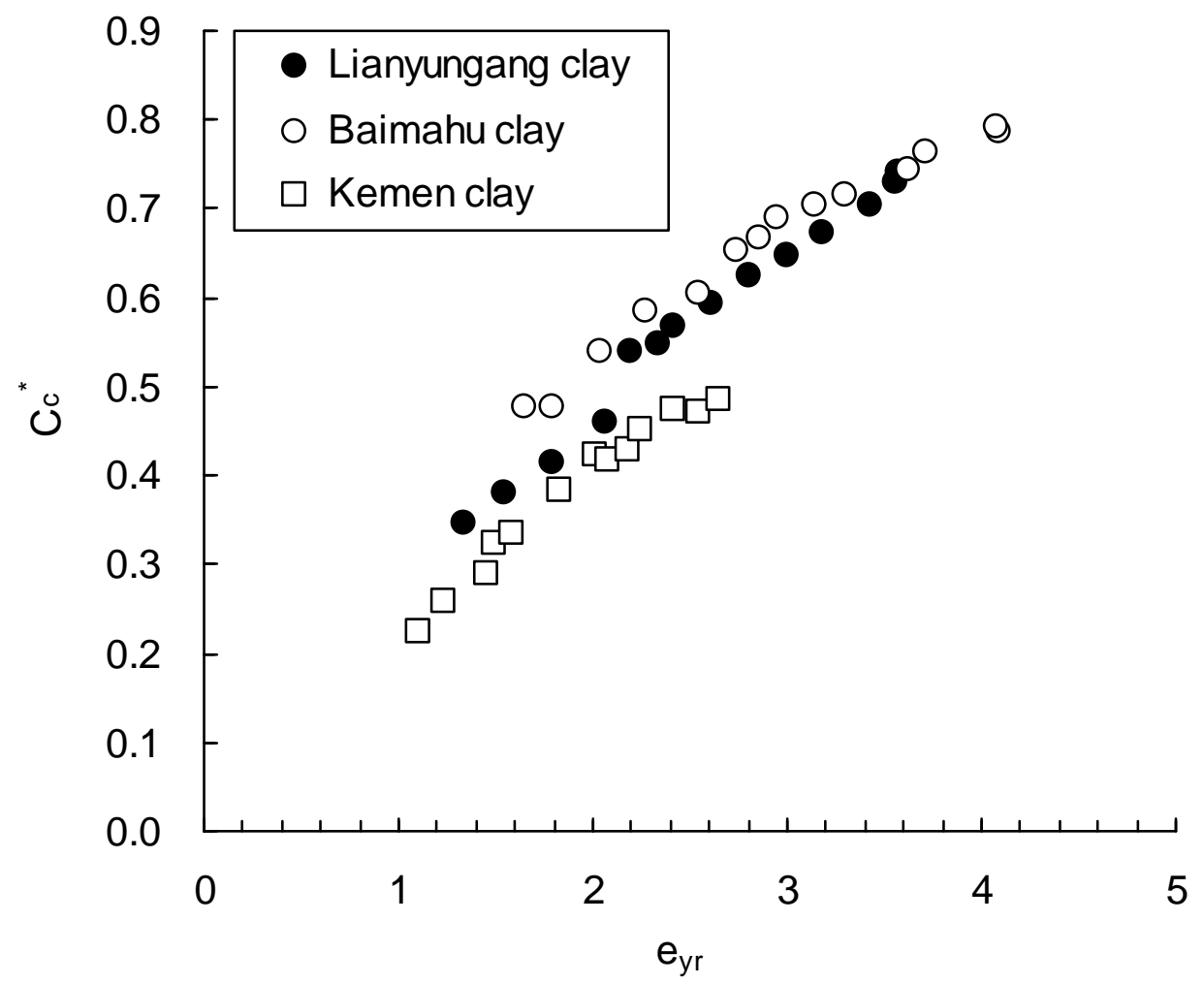

Fig. 2. Relationship between $C_{c}{ }^{*}$ and $e_{y r}$ for three reconstituted clays at different initial water contents 


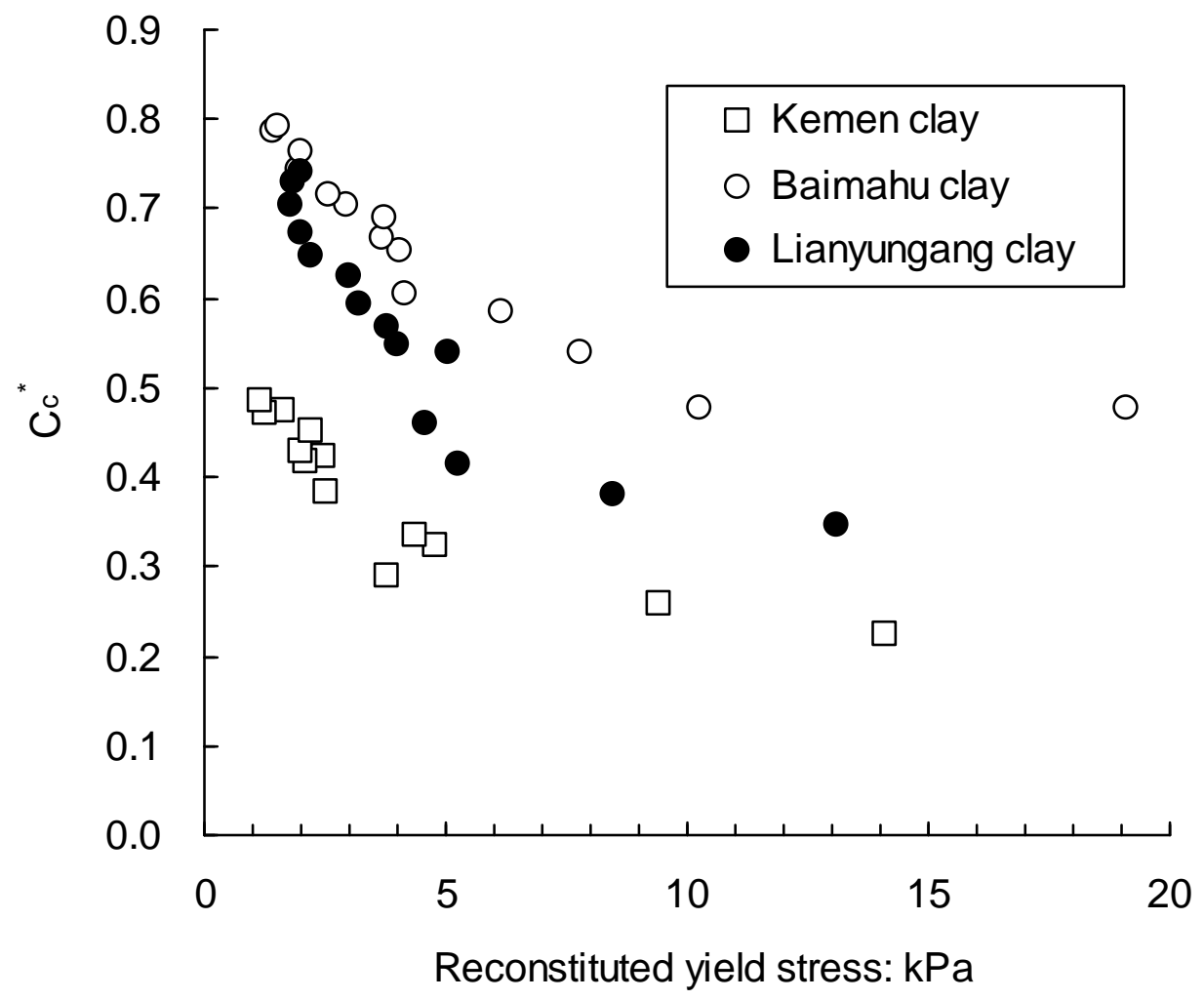

Fig. 3. Relationship between $C_{c}{ }^{*}$ and $\sigma_{y r}{ }^{\prime}$ for three reconstituted clays at different initial water contents 


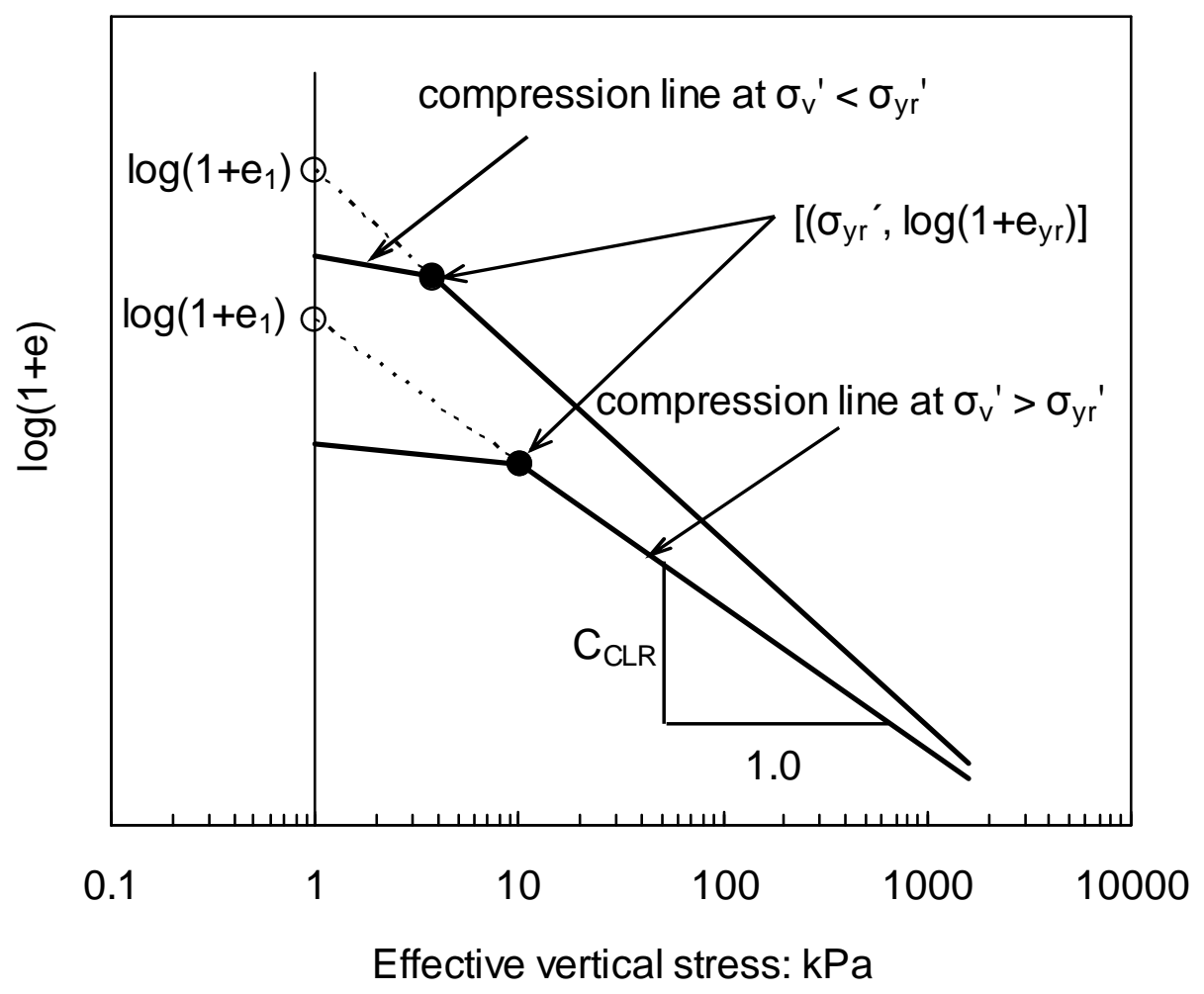

Fig. 4. Effect of starting points on compressibility for a given clay at different initial water contents 


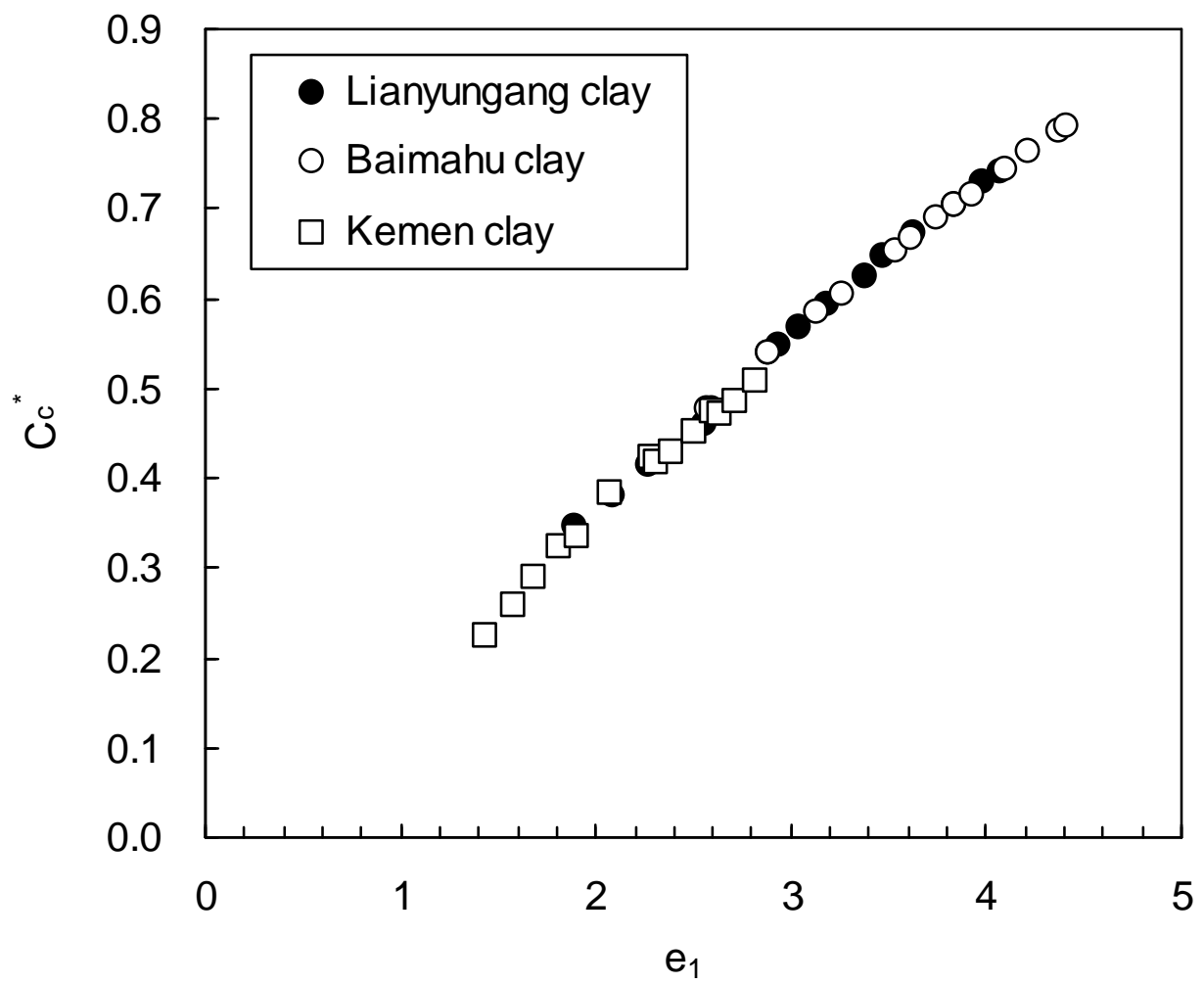

Fig. 5. Relationship between $C_{c}{ }^{*}$ and $e_{1}$ for three reconstituted clays at different initial water contents 


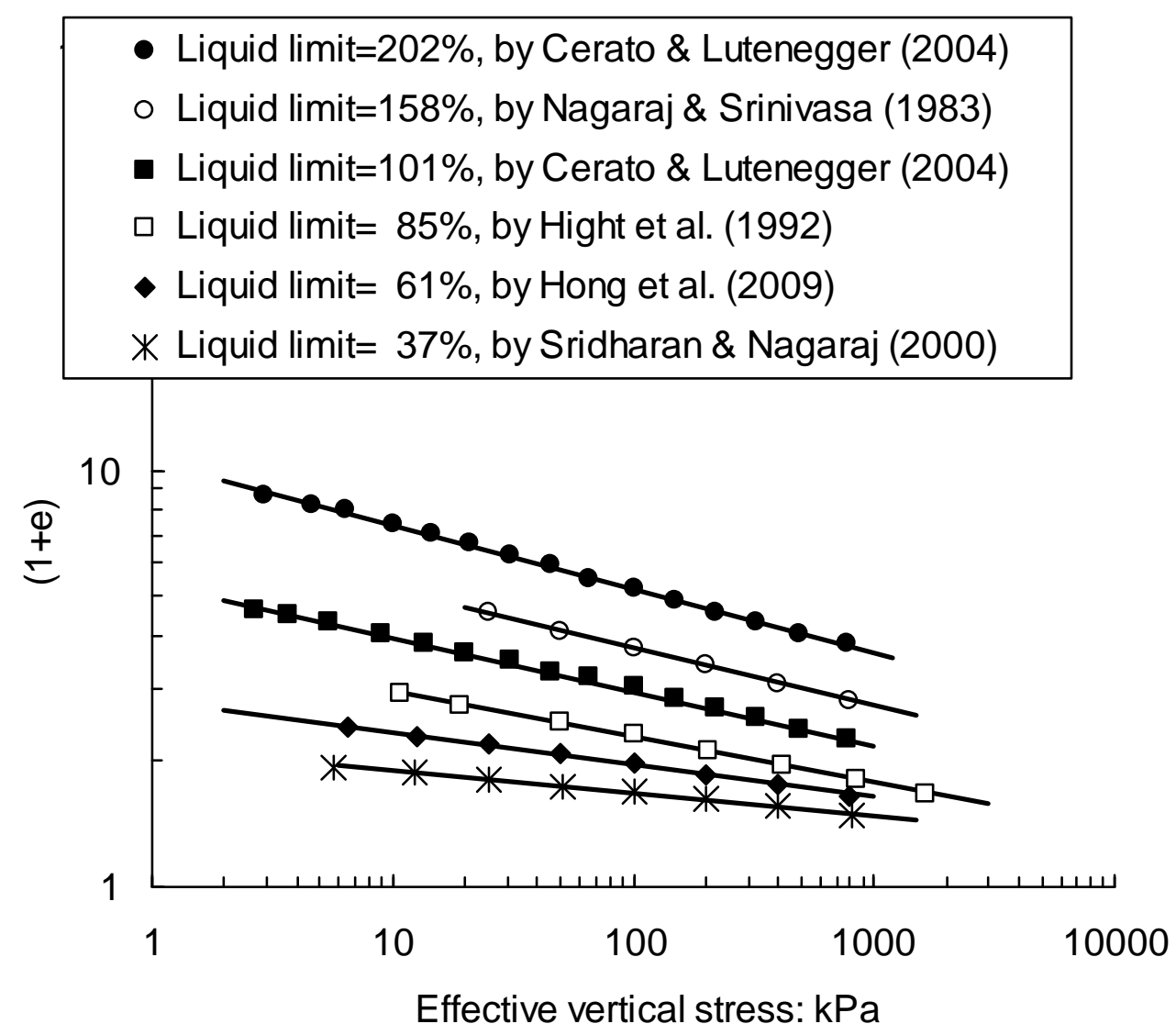

Fig. 6. Typical $\operatorname{linear} \log (1+e)-\log \sigma_{v}{ }^{\prime}$ lines of reconstituted clays at $\sigma_{\mathrm{v}}{ }^{\prime}>\sigma_{\mathrm{yr}}{ }^{\prime}$ 


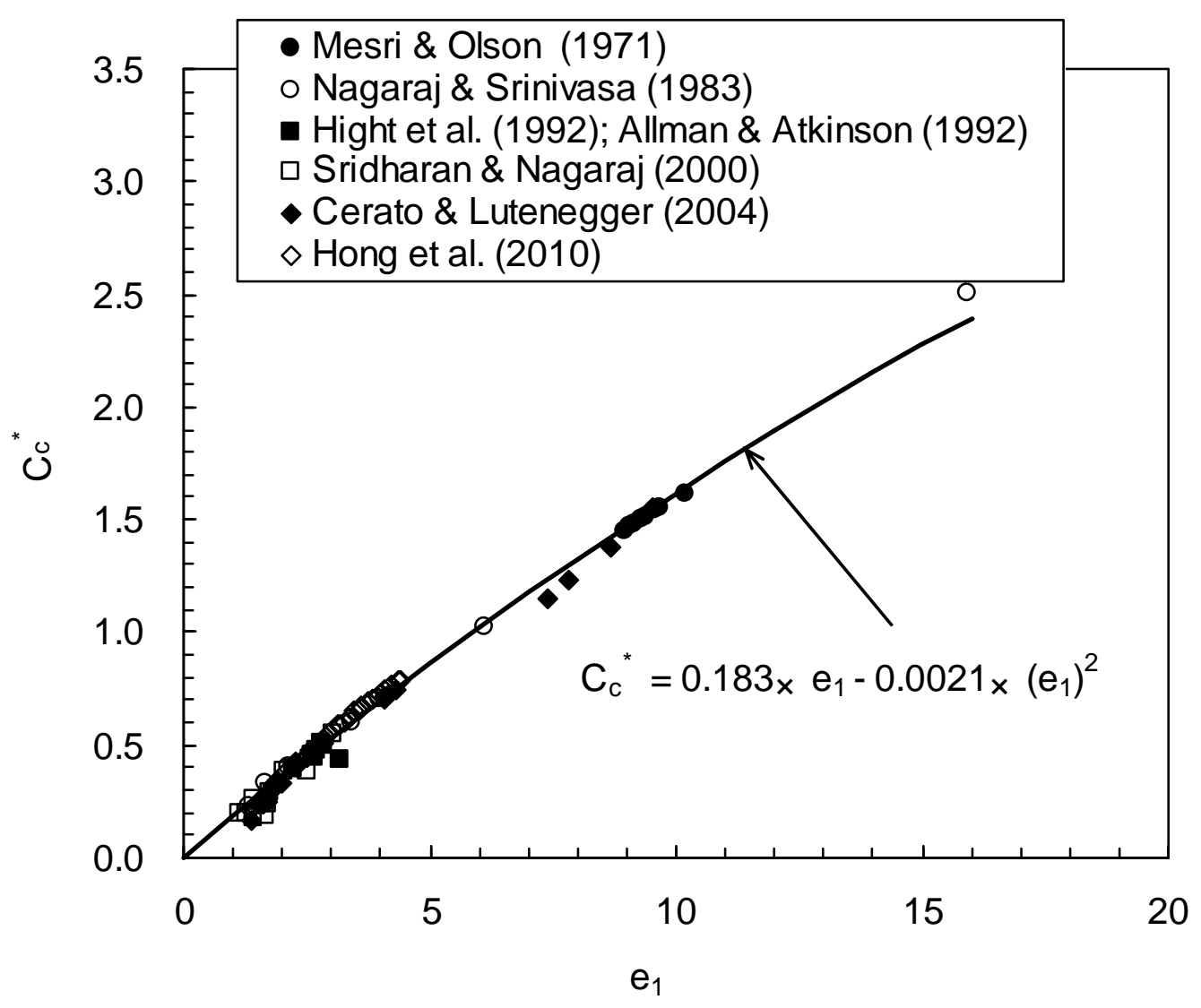

Fig. 7. Relationship of $C_{c}{ }^{*}$ versus $e_{1}$ for all 90 reconstituted clays 


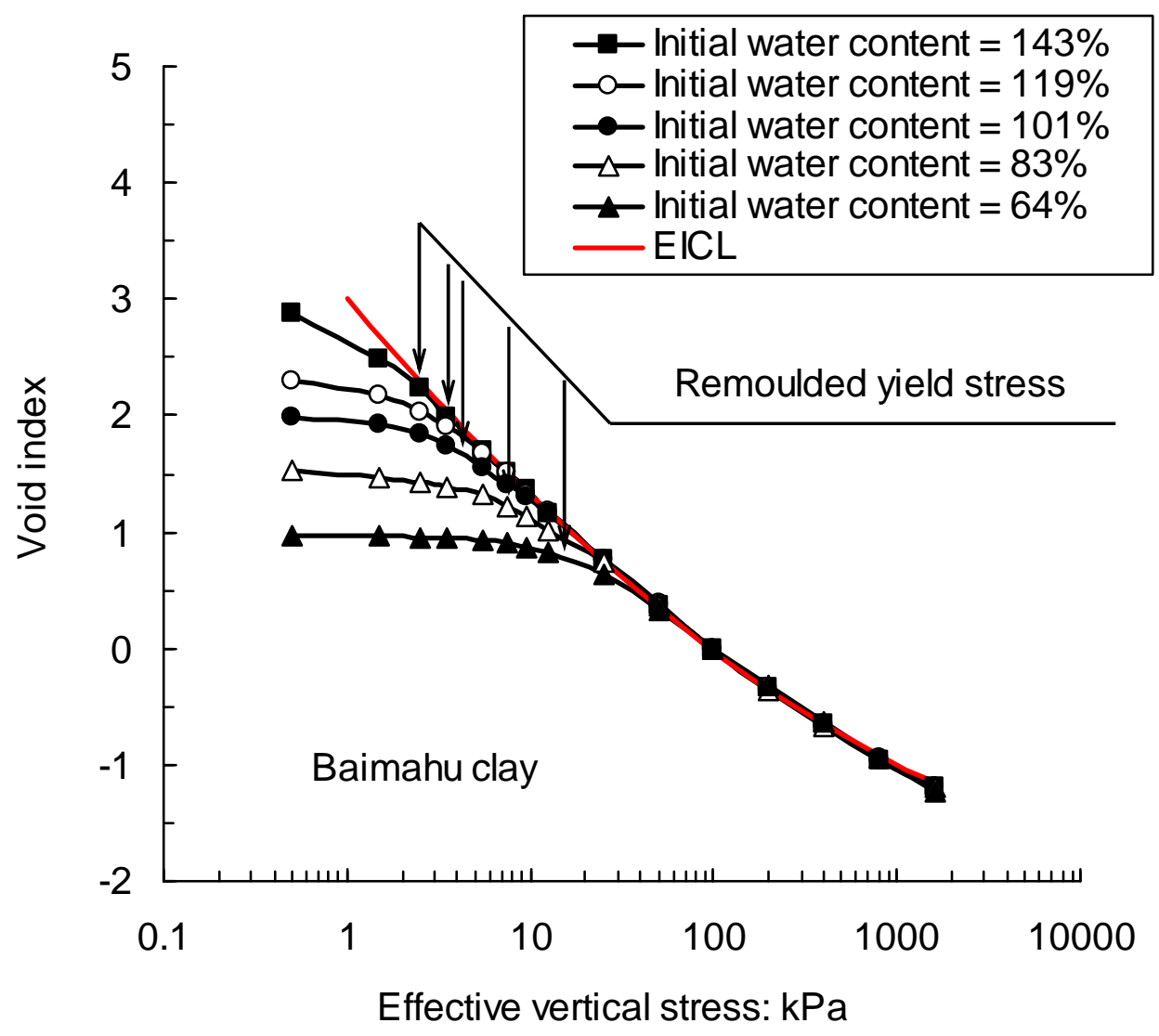

Fig. 8. Typical $I_{v}-\log \sigma_{v}{ }^{\prime}$ curves of reconstituted clays at different initial water contents 


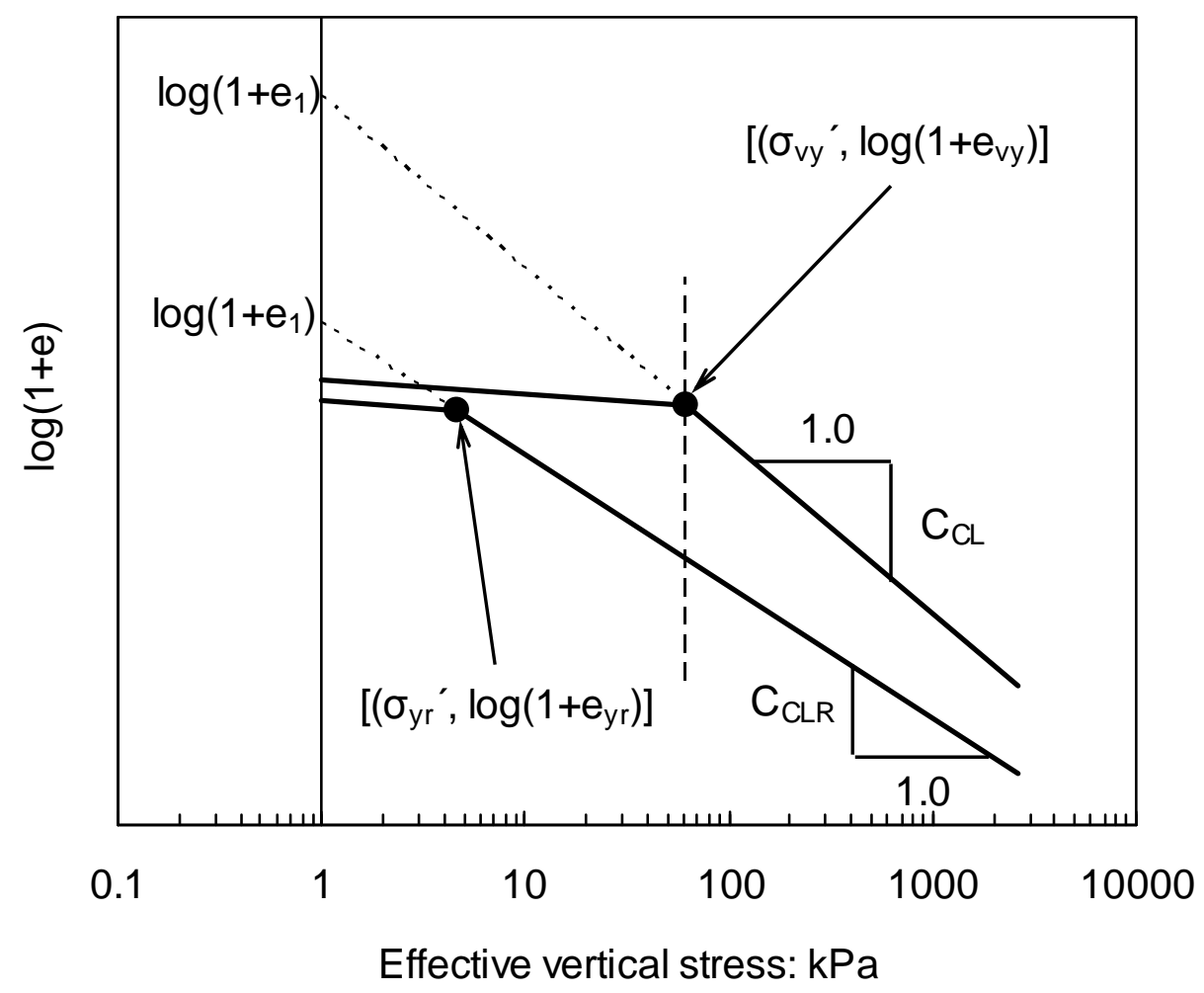

Fig. 9. Comparison of the starting points between undisturbed and remoulded specimens of natural clays 


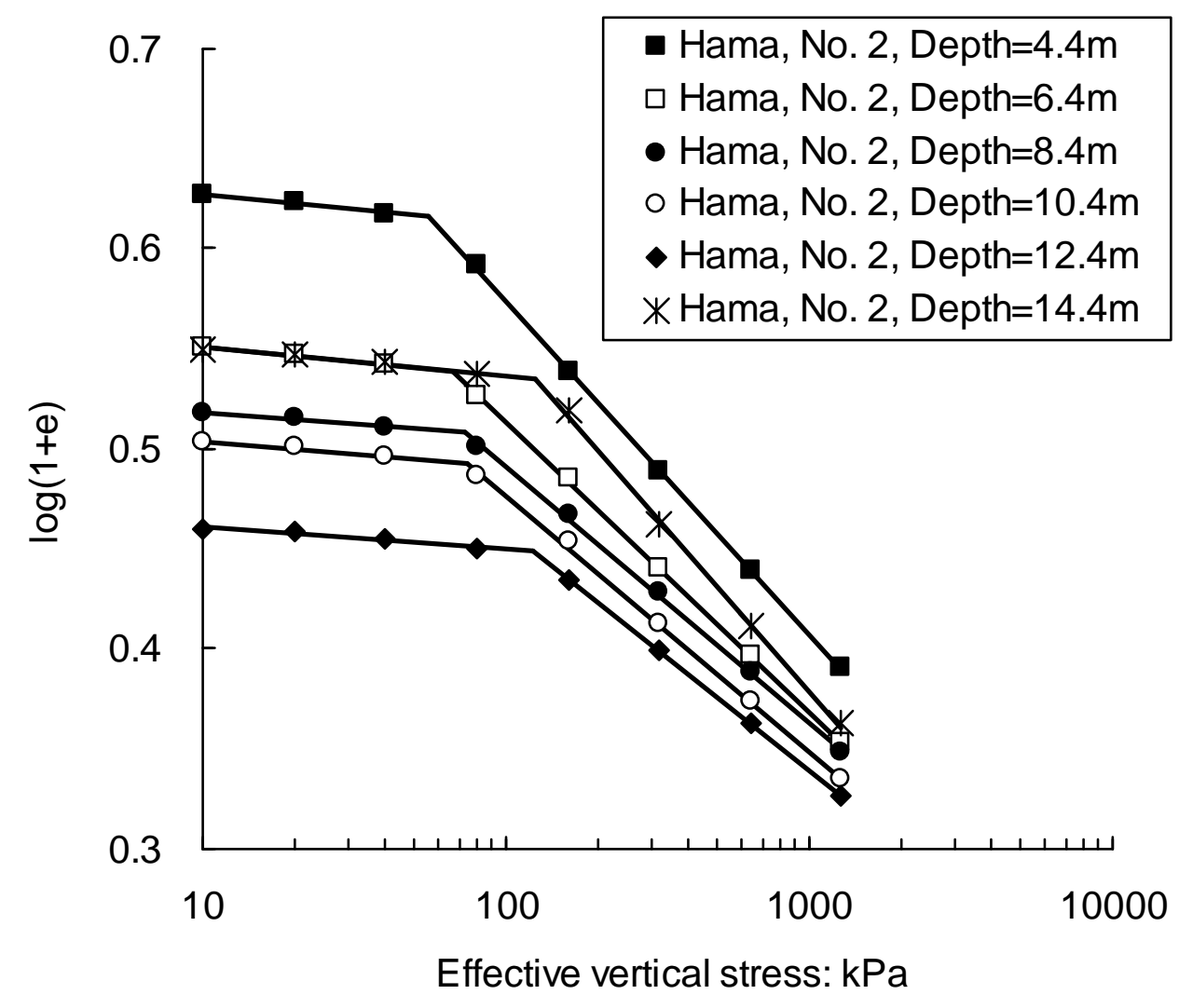

Fig. 10. Typical compression curves of natural Ariake clays in $\log (1+e)-\log \sigma_{v}{ }^{\prime}$ plot 


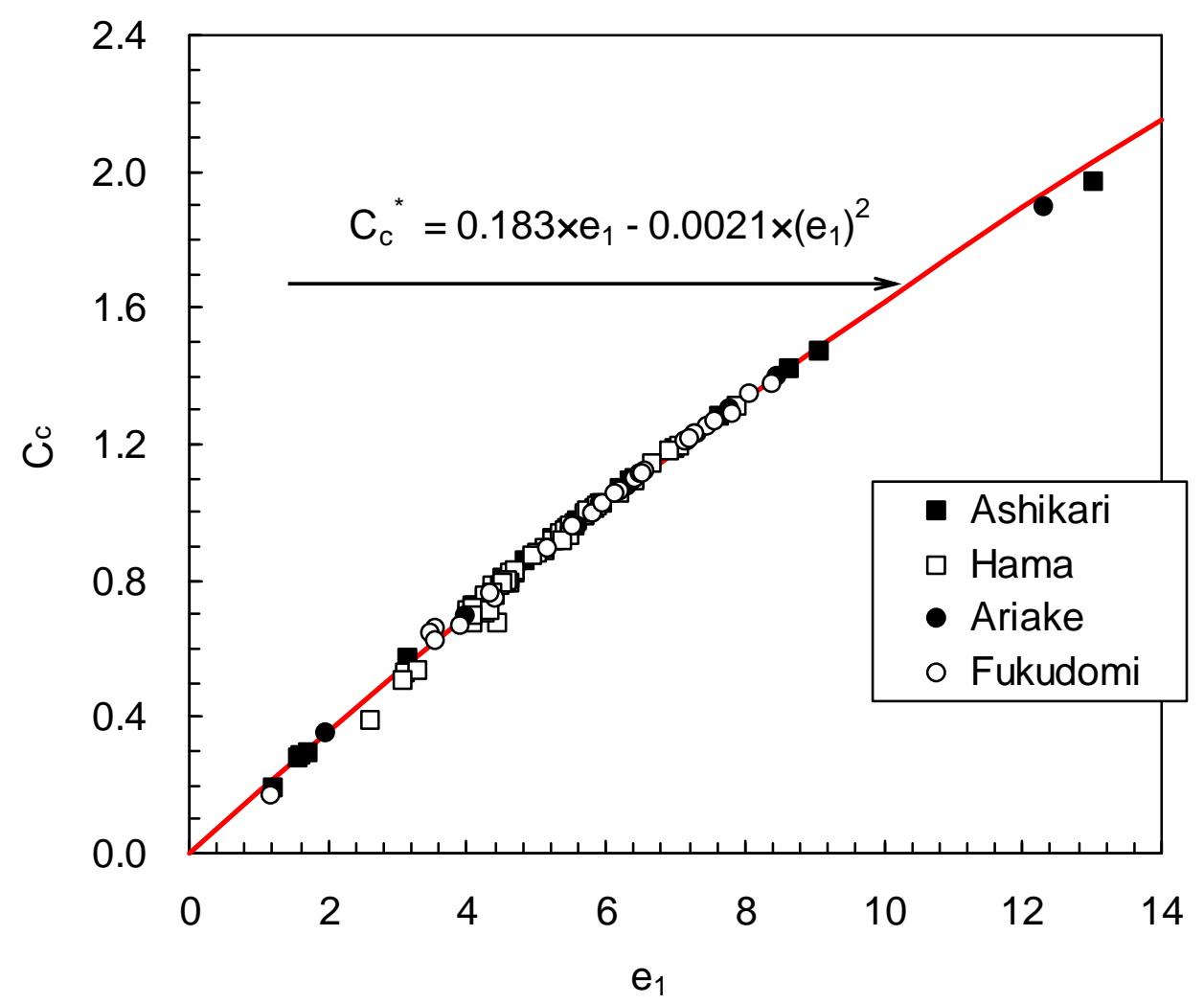

Fig. 11. Relationship between $C_{c}$ and $e_{1}$ for 119 natural Ariake clays 


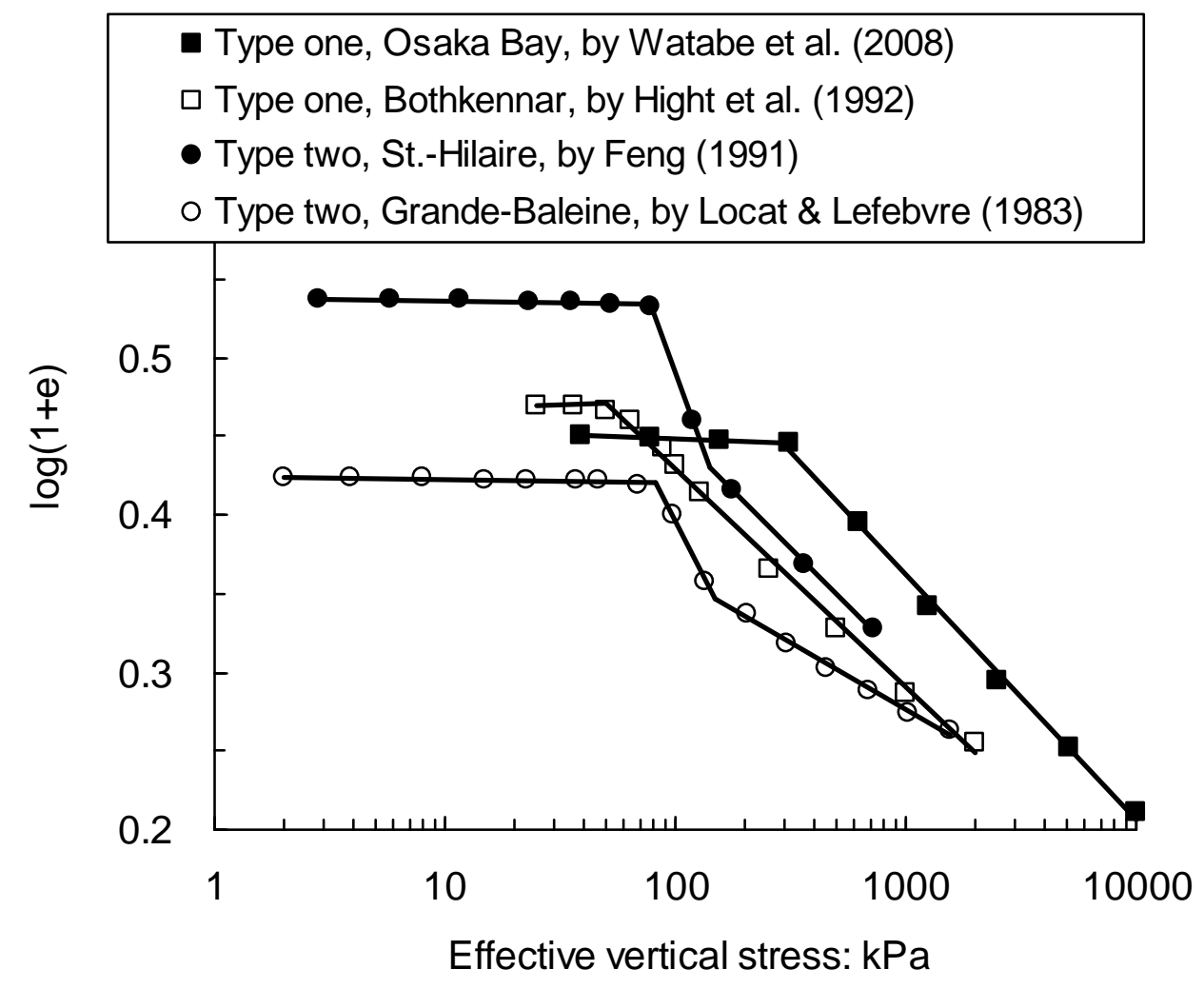

Fig. 12. Typical compression curves of two types of natural clays listed in Table 3 


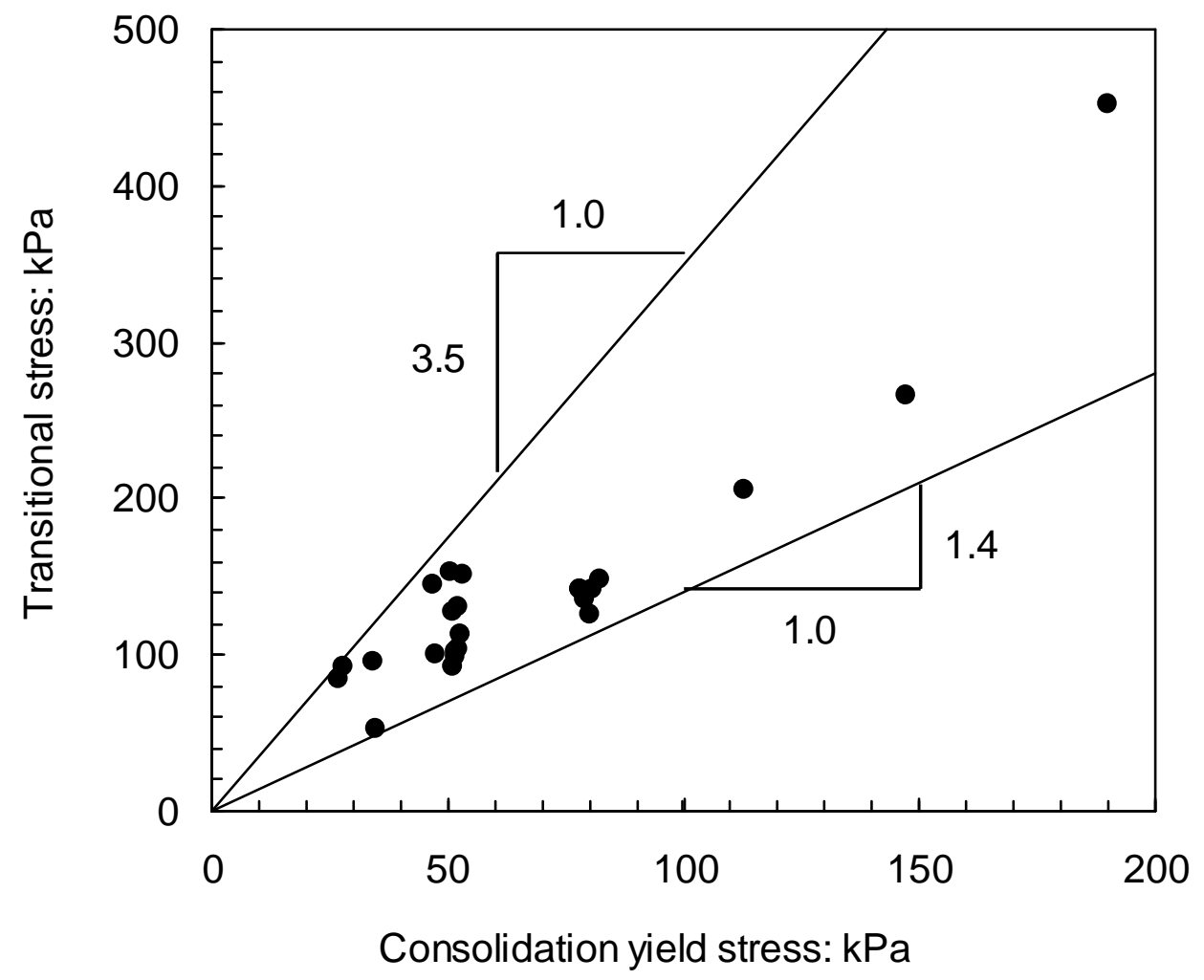

Fig. 13. Relationship between transitional stress and consolidation yield stress for natural clays of Type two listed in Table 3 


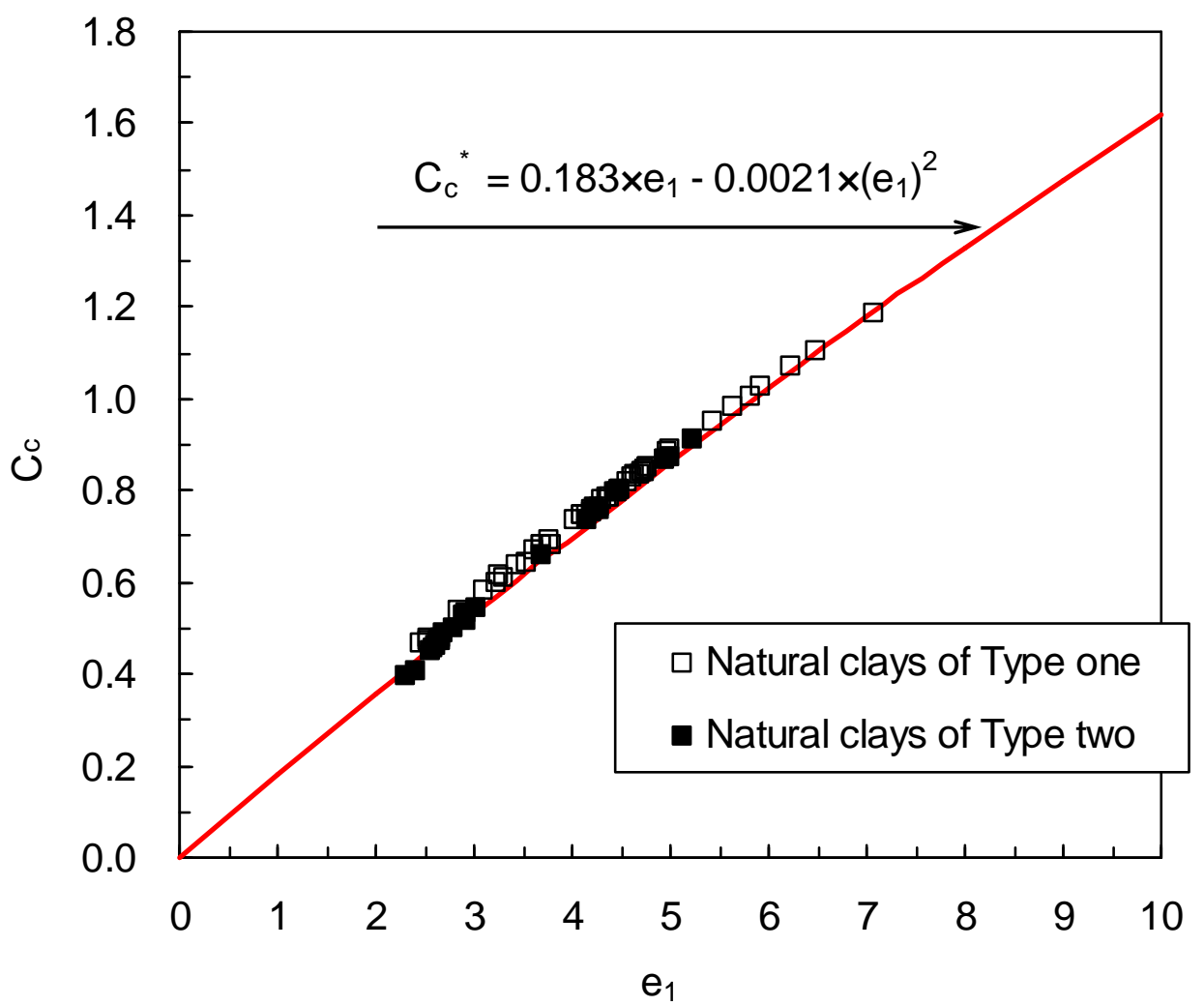

Fig. 14. Relationship between $C_{c}$ and $e_{1}$ for the two types of natural clays listed in Table 3 


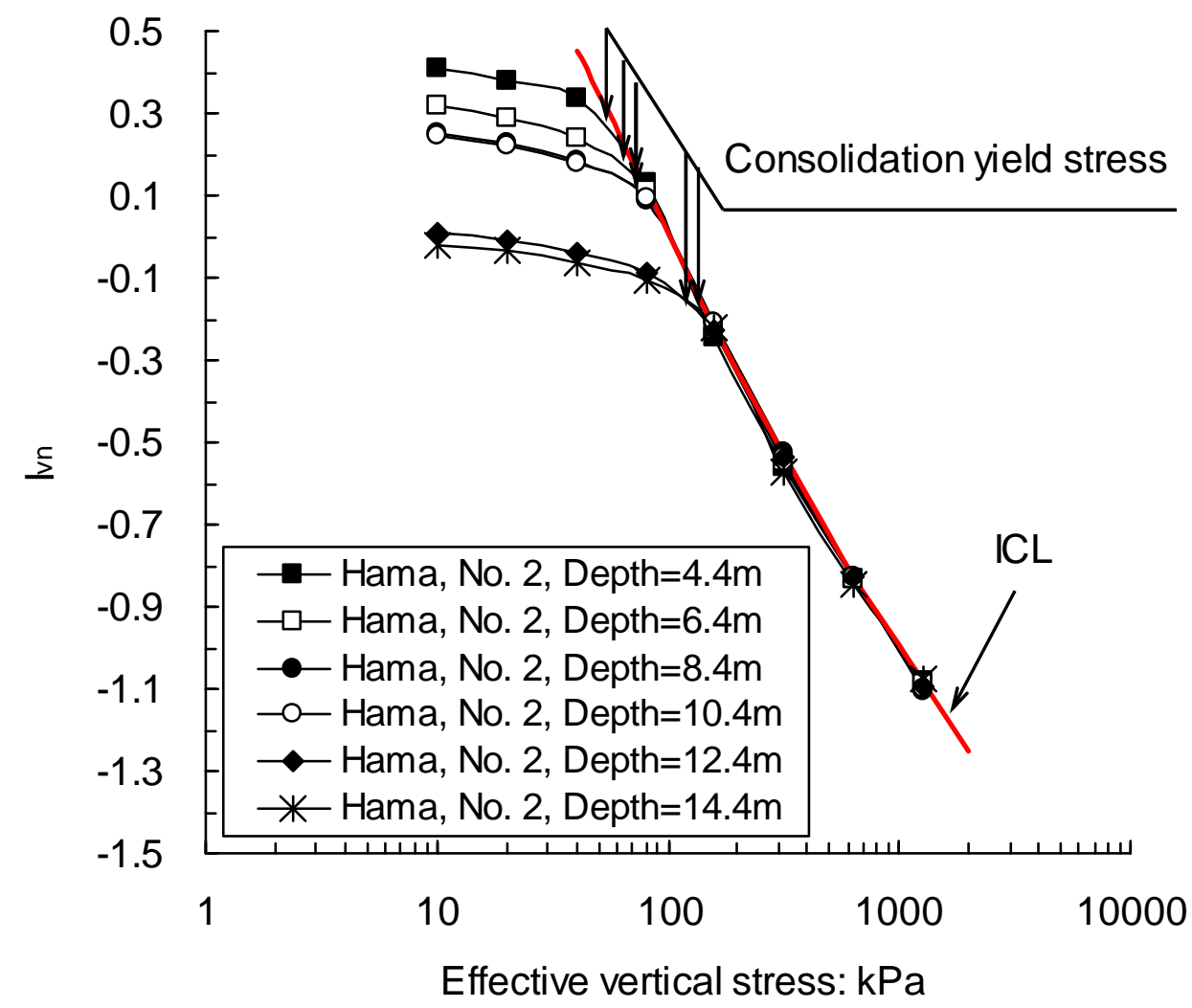

Fig. 15. Typical normalized behaviour of natural Ariake clays with void index $I_{v n}$ 


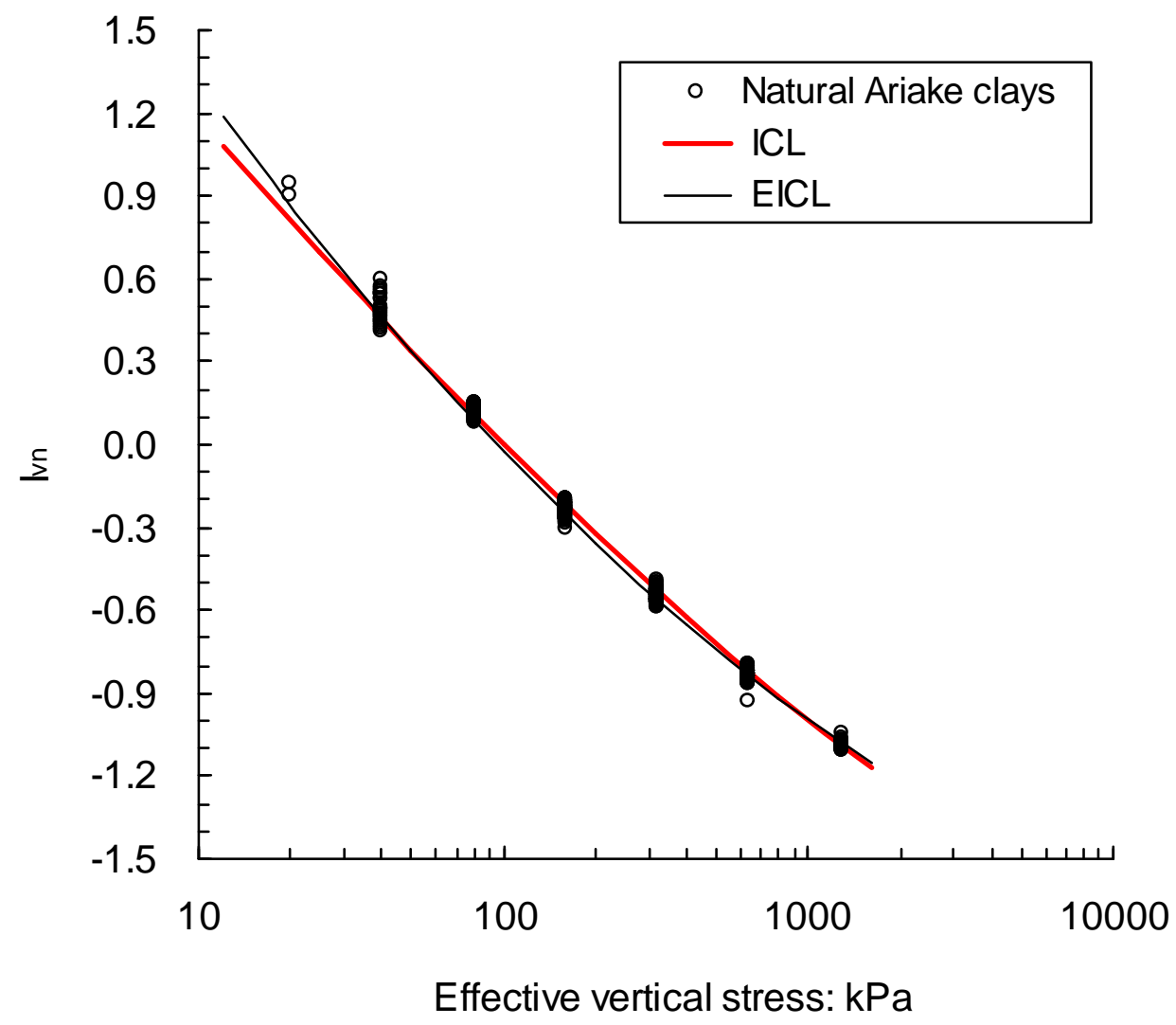

Fig. 16. Normalised line of 119 natural Ariake clays in post-yield regime 


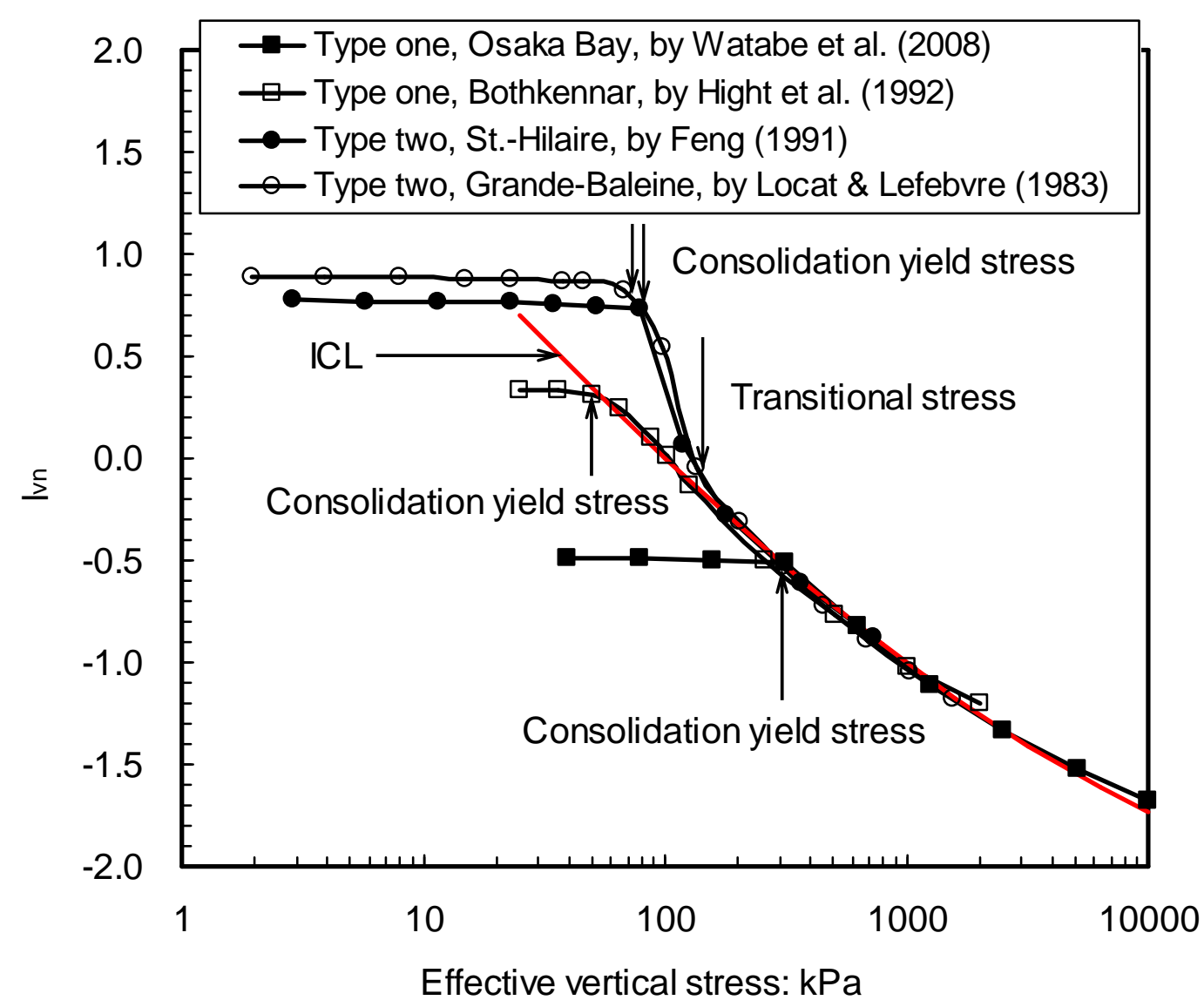

Fig. 17. Typical normalised behaviour with void index $I_{v n}$ for two types of natural clays listed in Table 3 


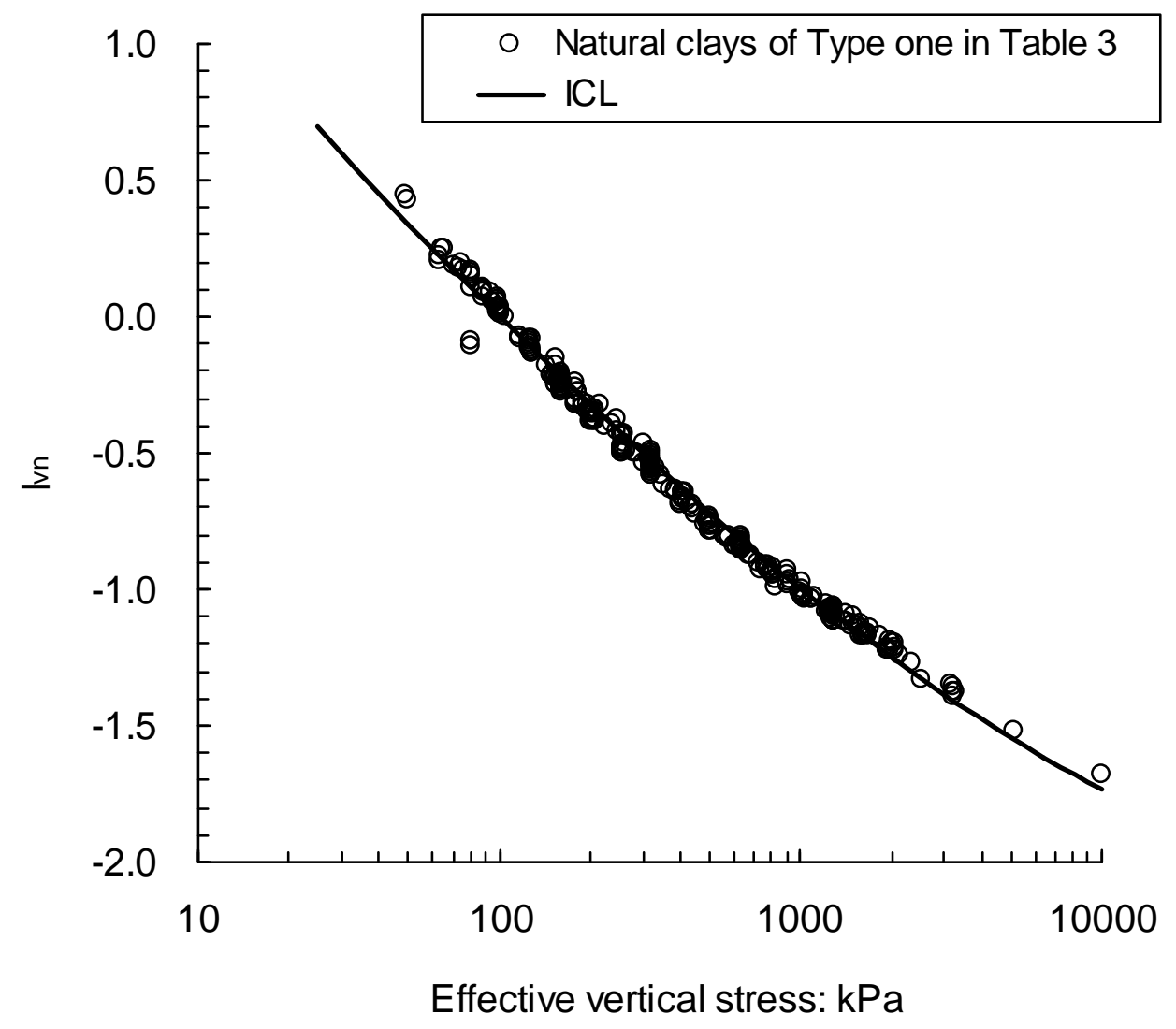

Fig. 18. Normalised behaviour with void index $I_{v n}$ for natural clays of Type one in post-yield regime 


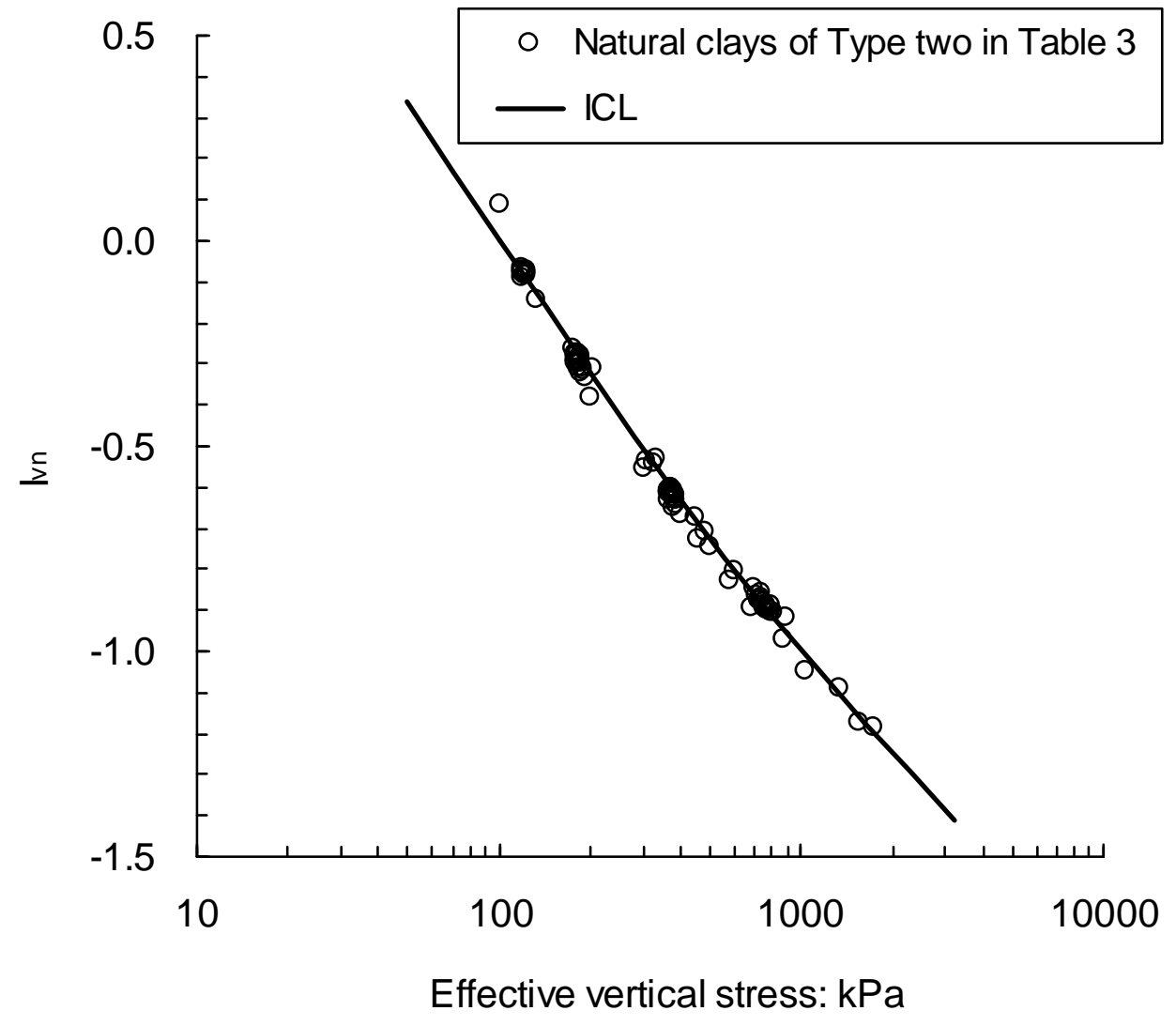

Fig. 19. Normalised behaviour with void index $I_{v n}$ for natural clays of Type two with effective vertical stresses larger than transitional stresses 